\title{
1 Uncertainties of sandy shoreline change projections as sea level rises
}

2

3 Gonéri Le Cozannet ${ }^{1, *}$, Thomas Bulteau ${ }^{2}$, Bruno Castelle ${ }^{3}$, Roshanka Ranasinghe ${ }^{4}$, Guy Wöppelmann ${ }^{5}$, Jeremy Rohmer ${ }^{1}$, Nicolas Bernon ${ }^{2}$, Déborah Idier ${ }^{1}$, Jessie Louisor $^{1}$. David Salas-y-Mélia ${ }^{6}$

5 1. BRGM, 3, av. Claude Guillemin, BP 36009, 45060 Orleans Cedex 2, France,

6 g.lecozannet@brgm.fr, +33238643614 (Corresponding author)

7 2. BRGM, French Geological Survey, Pessac, France

8 3. CNRS/Univ. Bordeaux, Pessac, France

9 4. IHE Delft/University of Twente/Deltares, The Netherlands

5. LIENSs, CNRS - Université de La Rochelle, France

6 CNRM, Université de Toulouse, Météo-France, CNRS, Toulouse, France

* Contact information:

13 Dr. Gonéri Le Cozannet

14 3, avenue Claude Guillemin

1545060 , Orléans

16 France

17 g.lecozannet@brgm.fr 


\section{Significance statement}

Some of the most inhabited and developed land zones in the world are located close to the coasts. With increasing concerns regarding coastal risks and sea level rise, shoreline change projections are required for adaptation planning. Sea level rise is an important, but not the unique, source of uncertainties in shoreline change projections for the coming decades and centuries. We show that coastal impact models are uncertain as well, as they account for $20 \%$ to $40 \%$ of shoreline changes uncertainties by 2100 and beyond over 4 contrasted sandy beach-dune systems in south-western France. This means that together with continued research to provide sea level projections, more observations and research on coastal evolution is needed to inform coastal adaptation.

\section{$\underline{\text { Abstract }}$}

Sandy shorelines are constantly evolving, threatening frequently human assets such as buildings or transport infrastructures. In these environments, sea level rise will exacerbate coastal erosion to an amount which remains uncertain. Sandy shoreline change projections inherits the uncertainties of future mean sea level changes, of vertical ground motions, and of other natural and anthropogenic processes affecting shoreline change variability and trends. Furthermore, the erosive impact of sea level rise itself can be quantified using two primary different coastal impact models. Here, we show that this latter source of uncertainty, which has been little quantified so far, can account for 20 to $40 \%$ of the variance of shoreline projections by 2100 and beyond. This is demonstrated at four contrasted sandy beaches relatively unaffected by human interventions in south-western France. Over these four sites, a variancebased global sensitivity analysis of shoreline projections uncertainties can only be achieved owing to previous observations of beach profile and shoreline changes. This means that sustained coastal observations and efforts to develop sea level rise impact models are needed to understand and eventually reduce uncertainties of shoreline change projections, in order to ultimately support coastal land use planning and adaptation. 
2 Since 1870, sea level is rising, mainly due to the melting of land-ice and the ocean expansion caused by

anthropogenic climate warming (Church and White, 2006; Church et al., 2013; Dangendorf et al., 2017; Dieng et al., 2017; Chen et al., 2017). While the most immediate impact of sea level rise is increased coastal flooding hazards (Nicholls and Cazenave, 2010; Woodworth et al., 2011; Hallegatte et al., 2013; Hinkel et al., 2014; Sweet and Park, 2014; Wahl et al., 2017; Vitousek et al., 2017a, Moftakhari et al., 2017), there are significant concerns regarding shoreline retreats as well (Leathermann et al., 2000; Stive, 2004; Nicholls and Cazenave, 2010; Hinkel et al., 2013; Cazenave and Le Cozannet, 2014; Ranasinghe, 2016; Vitousek et al., 2017b; Jiménez et al., 2017; De Winter and Ruessink, 2017; Enríquez et al., 2017). In particular, beaches backed by sandy deposits are receiving a particular attention for several reasons: first, they represent $31 \%$ of the world's ice-free coasts (Luijendijk et al., 2018); second, they are potentially highly sensitive to sea level changes; third, it has been estimated that at least $24 \%$ and up to $70 \%$ of the world beaches are already under chronic erosion, although with large regional and local differences (Luijendijk et al., 2018; Bird, 1985); finally, beaches are both valuable for tourism and as buffer zones during extreme events such as storms.

Sandy shoreline change projections along a given coast need to consider sediment losses and gains caused by a number of hydro-sedimentary processes acting at different timescales (Cowell et al., 2003). Coastal change is driven by a myriad of processes interacting with one another on a wide range of spatial and temporal scales, making process-based coastal evolution modelling hardly applicable at operational levels. Hence, coastal adaptation practitioners have pragmatically relied on extrapolations of past observations in order to anticipate future shoreline changes. In the absence of human interventions, estuaries or other major sediment source or sink, this results in the following equation:

$L_{r}=L_{r 0}+n \cdot T x+L v a r+\Delta S_{s l r}$

where $L_{r 0}$ and $L_{r}$ are the shoreline positions in a cross-shore direction at the initialization and after $n$ years, respectively, $T x$ is the linear trend over multi-decadal to centennial timescales, Lvar represents the seasonal, inter-annual and decadal modes of variability of shoreline changes. Finally, the term $\Delta S_{s l r}$ 
quantifies the impacts of relative sea level changes, that is, those due to ocean thermal expansion, land water and ice contributions and vertical ground motions (uplift or subsidence) (Stammer et al., 2013). It is denoted "coastal impact model" hereafter.

In the area of coastal prospective planning, a comprehensive description of the uncertainties of future shoreline position is required in order to avoid maladaptation (Magnan et al., 2016). Shoreline change projections based on equation (1) need to consider the uncertainties of future sea level rise under different climate forcing (Church et al., 2013; Kopp et al., 2014), of local vertical ground motions (Wöppelmann and Marcos, 2016), of other modes of variability of shoreline positions (Tx and Lvar), as well as uncertainties of coastal impact models $\left(\Delta S_{s l r}\right)$. The latter source of uncertainty has not been quantified so far.

We estimate the uncertainties of coastal impact models $\left(\Delta S_{s l r}\right)$ by considering the difference between two existing approaches: the Bruun rule (1962) and the Probabilistic Coastline Recession model (Ranasinghe et al., 2012). The Bruun rule is the most commonly used and historical approach to assess sea level rise impacts on shorelines (Bruun, 1962; Davidson-Arnott, 2005). It assumes a landward translation of the beach profile as sea level rises. The Probabilistic Coastline Recession model (PCR) is a recently introduced approach that quantifies sediment losses at the dune toe during storms, as well as the nourishment of the dune by aeolian sediment transport processes between storms (Ranasinghe et al., 2012). Over multi-decadal timescales, the superimposition of unchanged storms with rising mean sea levels results in more frequent and larger sediment losses in the PCR model. The Brunn rule and the PCR models are not only based on different assumptions regarding the physical processes guiding the response of sandy shorelines to sea level rise, but they also provide different results: where the PCR approach has been applied, the predicted shoreline retreats were lower than those predicted by the Bruun rule by one order of magnitude (Ranasinghe et al., 2012; Li et al., 2014; Wainwright et al., 2015; Toimil et al., 2017). Today, both coastal impact models are equally difficult to validate due to the scarcity of coastal data and the complexity of hydrosedimentary processes involved (Cooper and Pilkey, 2004; Cowell et al., 2006). Faced with this deep uncertainty, stakeholders concerned with coastal adaptation generally lack the relevant observations to validate one particular model, and may therefore assign an 
equal confidence to both. Hence, the difference between the Bruun and PCR models can be considered as a first order measure of the coastal impact model error.

Equation (1) requires coastal data, which are not available at global scale. Hence, we implement the approach at four contrasted coastal sites of the sandy coast of Aquitaine in Southern-France (Supplementary Material 1,2 and 3). These sites are chosen because they are representative of the range of variability and trends in shoreline positions (Supplementary Material 1 and 4): sites \#1 and \#2 are stable today, whereas sites \#3 and \#4 are eroding (sum of $T x$ and of the effects of present-days sea level rise in equation (1)). The variability around this trend (Lvar term in equation (1)) reaches $+/-21 \mathrm{~m}$ at site $\# 3$, approximately $+/-9 \mathrm{~m}$ at site $\# 2$ and $\# 4$ and only $+/-3.2 \mathrm{~m}$ at site $\# 1$. Furthermore, site $\# 2$ is located close to a permanent GNSS station, providing a precise evaluation of vertical ground motions (subsidence or uplift) and of its contribution to relative sea level changes. The uncertainties of vertical ground motions at site \#2 are estimated from the SONEL database (Santamaria-Gomez et al., 2017), while those at sites $\# 1, \# 3$ and $\# 4$ are based on a global analysis of coastal vertical ground motions based on GNSS measurements and GIA modeling. Hence, site \#2 provides a testbed to appraise the usefulness of such GNSS instrumentation to reduce uncertainties of shoreline change reconstructions and projections.

We compute shoreline change projections for the four coastal sites in Aquitaine by means of a MonteCarlos procedure, within which probabilistic input parameters (Table 1) are propagated through equation (1) (Anderson et al., 2015; Vitousek et al., 2017b). We estimate past regional sea level changes and their uncertainties using tide gauge records and permanent GNSS stations allowing to appraise coastal vertical ground motions (Santamaria-Gomez et al., 2017; Figure 1). We use the future sea level rise projections provided by Kopp et al. (2014) that we correct from local vertical ground motions (Figure 1; see Methods, subsection 1). The probabilistic sea level projections used here (Kopp et al., 2014) are essentially consistent with the $5^{\text {th }}$ Assessment Report of the International Panel on Climate Change (IPCC) (Church et al., 2013), which remains today the reference source of information from the perspective of coastal adaptation practitioners (see the discussion section). The other terms in equation (1) are evaluated empirically, based on past observations of $L_{r}$ obtained through various data (e.g. 
1 historical charts, satellite and aerial photographs, shoreline surveys) available from the Aquitaine

2 Coastal Observatory (Supplementary Material 1 and 2). Assuming that no preference can be given to

3 the PCR model or the Bruun rule from a coastal management perspective, the two coastal impact models

4 are selected alternatively (see Methods, subsection 2).
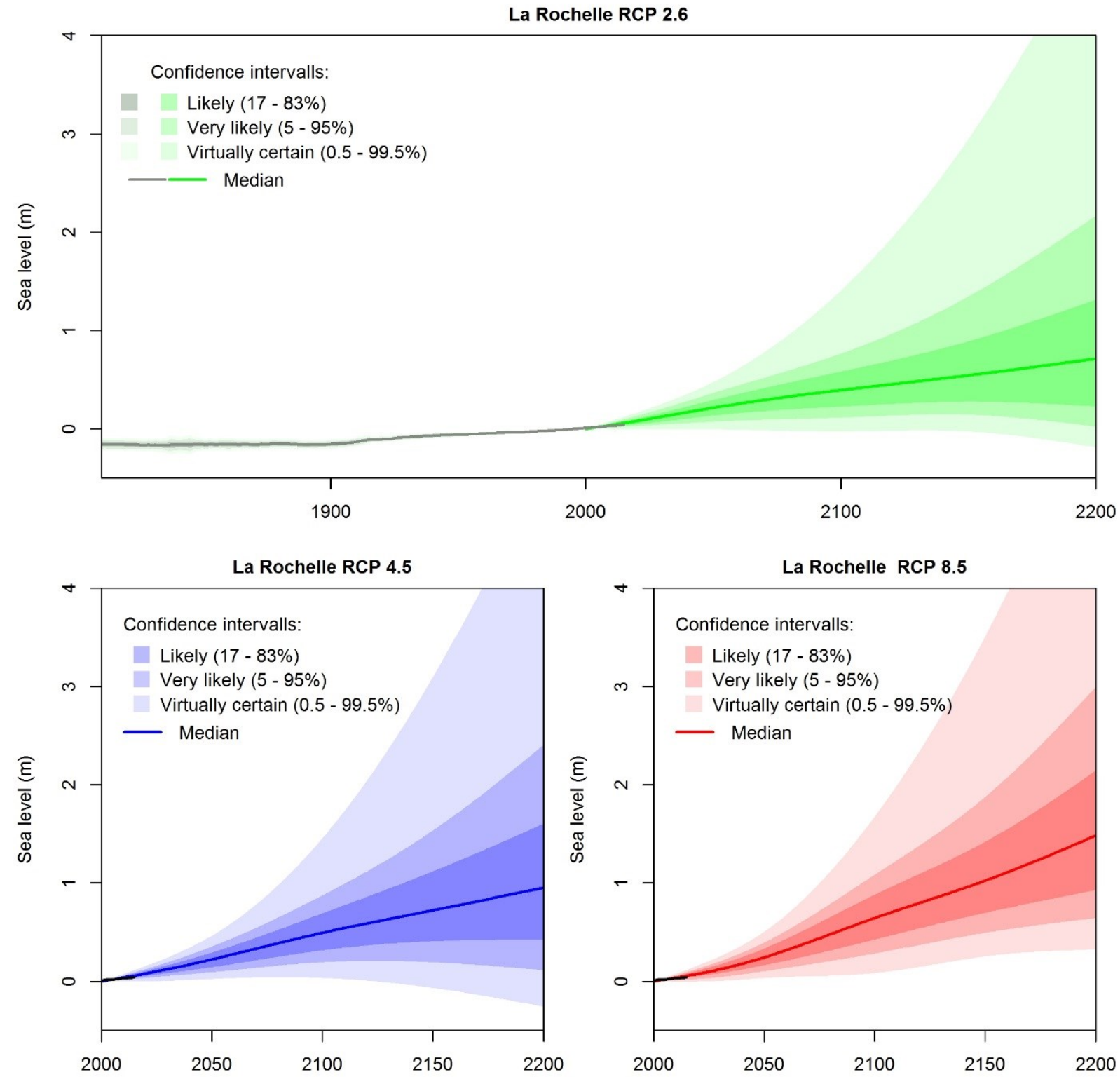

6 Figure 1: sea level reconstructions and projections used in this study (source of projections: Kopp et

$7 \quad$ al., 2014; Reconstruction: see Methods, subsection 1)

8 We evaluate the uncertainties of coastal impact models against all other sources of uncertainties using a

9 global sensitivity analysis (Saltelli et al., 2008) (see Methods, subsection 3). This latter procedure 
provides quantitative estimates of the contribution of each uncertain parameter to the variability of shoreline change projections, while addressing explicitly interactions between uncertain parameters involved in equation (1). The global sensitivity analysis involves a large number of simulations: the PCR model would be called approximately 100,000 times each year to reduce errors of sensitivity indices by less than $1 \%$. As the computation time of the PCR model is prohibitive for such a number of simulations, we use a surrogate model of the PCR model to reduce the computation time (see Methods, subsection 4 and Supplementary Material 5).

Our probabilistic approach delivers a range of contrasted shoreline change projections, showing that by 2100 and depending on the location of interest, the statistical uncertainties of sea level projections represent approximately half of those due to the choice of a particular coastal impact model (section 2). However, there remain residual uncertainties, whose probability is difficult to quantify, and which could bring future shoreline positions outside the range of probabilistic projections shown in section 2 (see section 3). Despite these residual uncertainties, this study shows that the uncertainties of coastal impact models should be considered in future global studies aiming at quantifying sea level rise impacts and their uncertainties.

\section{Results}

\subsection{Shoreline change projections}

This subsection presents the shoreline change reconstructions (1807 to 2014) and projections (2000 to 2200) obtained from the propagation of probabilistic uncertainties through equation (1) at the coastal site \#1 (for other sites, see Supplementary Material 6 to 11). Figure 2 (respectively Figure 3) provides shoreline change projections and reconstructions based equation (1) implementing the Bruun rule (respectively: surrogate PCR model) as coastal impact model. For consistency, the effects and uncertainties of past sea level changes have been included in past shoreline change positions as assumed in equation 1, although they are expected to remain small (Le Cozannet et al., 2014; Castelle et al., 2018). 
At each time-step from 1807 to 2200, Figures 2 and 3 provide the median shoreline positions along a cross-shore transect. In addition, the uncertainties of shoreline change projections are conveyed through confidence intervals, as in the IPCC terminology (Mastrandrea et al., 2010). Hence, the probability for a shoreline position to remain within a likely interval (most intense gray, green, blue or red colors) is at least $66 \%$. Note that according to these projections, there is a small probability that shorelines advance seaward in the future. This is because sea level rise projections of Kopp et al. (2014) neither exclude a decrease in the rate of sea level rise after some decades, nor a drop of sea level rise itself in the case of RCP4.5 and 2.6 (Figure 1). The uncertainties of the shoreline change projections are very large (50 to $100 \mathrm{~m}$ by 2200 ), especially for the simulations based on the Bruun rule (Figure 2). These uncertainties are analyzed in the following section by means of the global sensitivity analysis.

All median projections shown in Figures 2 and 3 involve shoreline erosion, which corresponds to the superimposition of a multi-decadal eroding trend at site \#1 with the effects of sea level rise. Retreat values are larger for scenarios with highest radiative forcing, with median values reaching $40 \mathrm{~m}$ and $100 \mathrm{~m}$ respectively for RCP4.5 and RCP 8.5 by 2100 with the projections based on the Bruun rules. Projections based on PCR are less sensitive to sea level rise, so that shoreline retreat values and the related statistical uncertainties are approximately five times smaller in Figure 3 compared to Figure 2 (note similar order of magnitudes in Supplementary Material 6 to 11 for sites \#2, \#3 and \#4). This agrees well with previous implementations of the PCR model or its variants in other types of coastal environments, which concluded that by 2100 , the Bruun estimate lies in the range of $4-40 \%$ exceedance probability with respect to the PCR estimates (Ranasinghe et al., 2012; Li et al., 2014; Wainwright et al., 2015; Toimil et al., 2017).

For coastal adaptation practitioners, such results mean that at similar coastal sites where building infrastructures are located close to the coast, the modeling approach based on the Bruun rule implies large shoreline retreats for high emission scenarios in a few decades from now, superimposing a trend of $0.5 \mathrm{~m} / \mathrm{yr}$ or more to current shoreline retreat rates. Such a change would be associated with expensive coastal protection measures or the relocation of numerous assets at risk. Conversely, RCP 2.6 and the PCR model are less erosive, so that no specific adaptation to sea level rise induced shoreline erosion 
1 would be required. In all cases, a strong increase of shoreline erosion is not expected before 2050, which

2 gives time to plan adaptation.

3
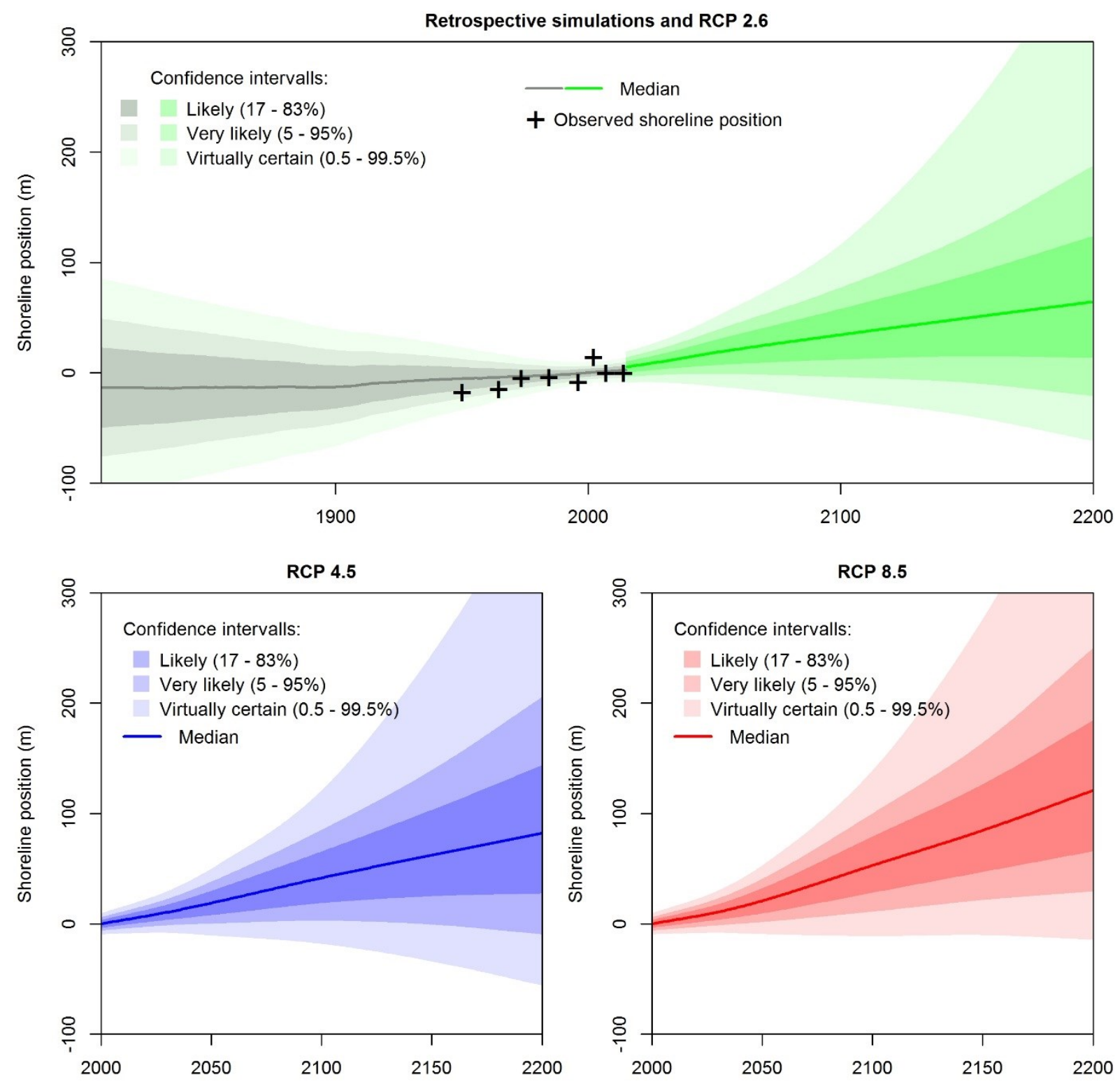

$5 \quad$ Figure 2: reconstructions and projections of shoreline positions using the Bruun rule exemplified at the

6 site \#1 (See Supplementary material 1, 3 and 4), provided in the form of median and confidence

7 intervals, displaying where the shoreline position is likely (respectively: very likely or virtually certain)

8 to lie at different timeframes from 1807 to 2200. The reference median shoreline position is arbitrarily

9 selected at 0 by 2000, with negative values corresponding to shoreline accretion (seaward) and positive to shoreline retreat (landward). These projections include uncertain beach slopes, vertical ground motions, sea level changes shoreline and change variability from events to inter-decadal timescales as 

well as an uncertain multi-decadal trend (see Methods). Note that sea level projections provided by

2 Kopp et al. (2014) consider that a sea level drop is possible (although very unlikely) beyond 2100

3 (Figure 1). Hence, shoreline changes below the median can bend downwards beyond 2100
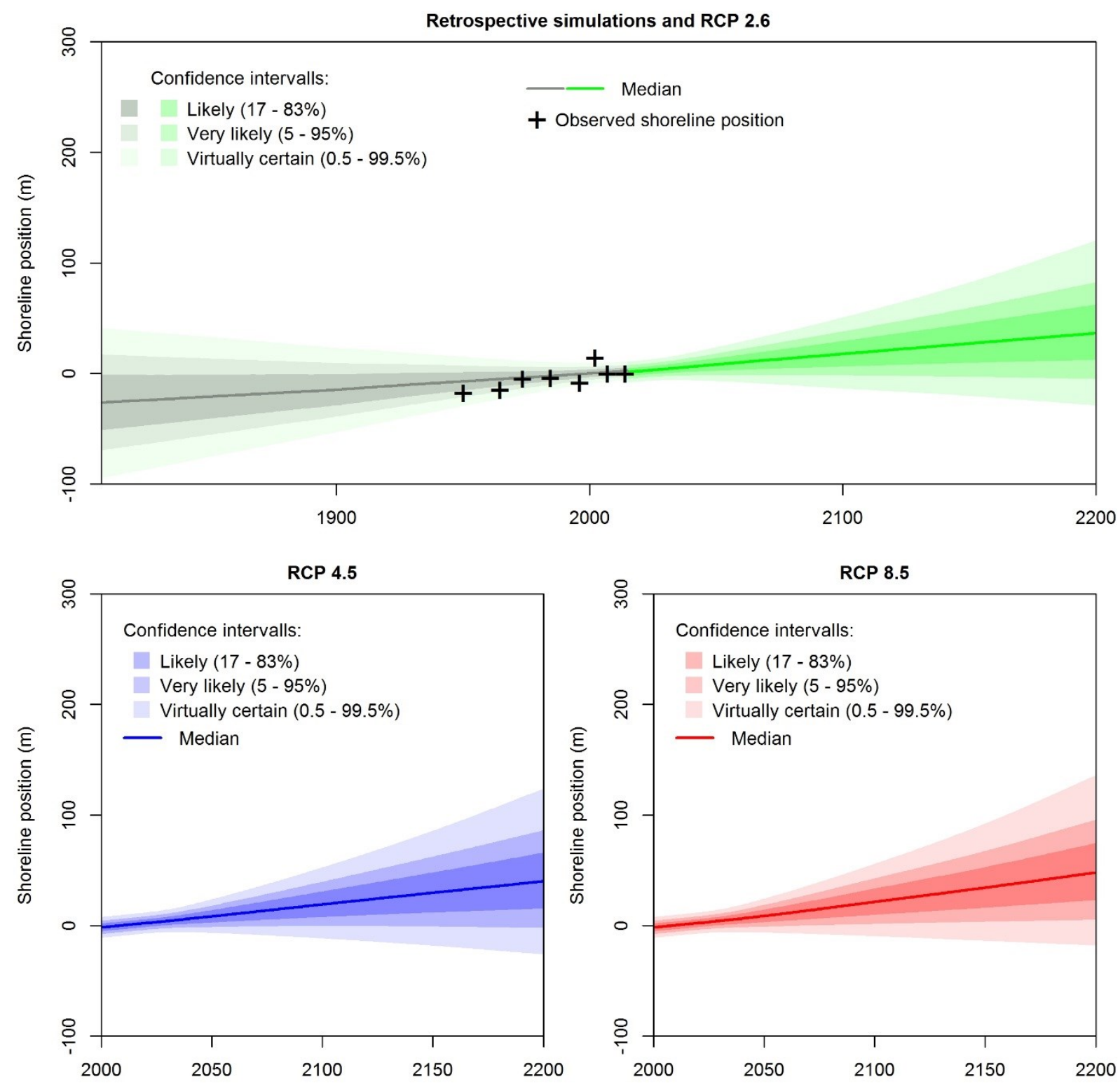

5 Figure 3: Same as Figure 2, with shoreline change projections and reconstructions using the PCR

6 coastal impact model.

\section{$7 \quad 2.2$ Variance-based global sensitivity analysis}

8 Figure 4 partitions the variance of shoreline change projections by displaying the main effects (i.e. $1^{\text {st }}$

9 order Sobol' indices) of the uncertain parameters in equation 1. This index is commonly interpreted as 
the expected proportion of the total variance of the shoreline change that would be removed if we were able to learn the true value of the uncertain parameter. It is commonly used to rank the importance of model parameters according to their impact for the variability of the model outcome (Saltelli et al., 2008).

The variance of shoreline change projections is partitioned differently depending on the period of time considered (Figure 4): uncertainties in the long term trends (not including sea level rise, that is, $T x$ in equation (1)) have a larger impact in the past (before 1950), whereas for present days, uncertainties are overwhelmingly due to the current modes of shoreline change variability, associated with the random nature of waves and currents at timescales ranging from days to decades through seasons (Lvar in equation (1)). Whatever the coastal site and the period of time considered, the uncertainties of the regional sea level reconstructions can be neglected with little impact to shoreline change projections, and so do the uncertainties of beach slopes estimations. Where vertical ground motions are known precisely from a permanent GNSS station, their impact on shoreline change projections is negligible (site \#2), whereas they can account up to almost $20 \%$ of the variance by 2050 at site \#1. Hence, while all sites considered are exposed to similar waves and tide conditions, the relative importance of each source of uncertainty varies along the coast depending on the local processes and the knowledge available.

If we knew which coastal impact model is correct, the variance of shoreline change projections could be reduced by $20 \%$ to $40 \%$ by 2100 depending on the coastal site of interest. Indeed, Figure 4 shows that for the sites $\# 1, \# 2$ and $\# 4$, the impact of this source of uncertainty grows rapidly over the coming decades, then peaks at $40 \%$ during the second half of the $21^{\text {st }}$ century, and finally decreases after 2100 , as sea level projections are becoming more uncertain and account for a larger fraction of the variance of shoreline change projections. For site \#3, the uncertainties of shoreline change trends and variability are much larger, thus reducing the fraction of variance that can be attributed to the choice of a coastal impact model. However, whatever the coastal site considered, the uncertainty due to coastal impact models accounts for twice the impact of the uncertainties of probabilistic sea level projections (yellow area in Figure 4). 
1 To summarize, the main sources of uncertainties of shoreline reconstructions and projections depend on

2 the local coastal settings and vary with time, with future sea level rise and the choice of a particular

3 coastal impact model becoming prominent beyond 2050. In terms of decision making, the different

4 sources of uncertainties can be addressed differently, either by trying to reduce them using new

5 observations wherever possible (e.g., of shoreline changes and vertical ground motions) (Cazenave et

6 al., 2017), or by selecting appropriate decision making frameworks to minimize the risks of

7 maladaptation despite uncertainties (Hinkel et al., 2015; Magnan et al., 2016).
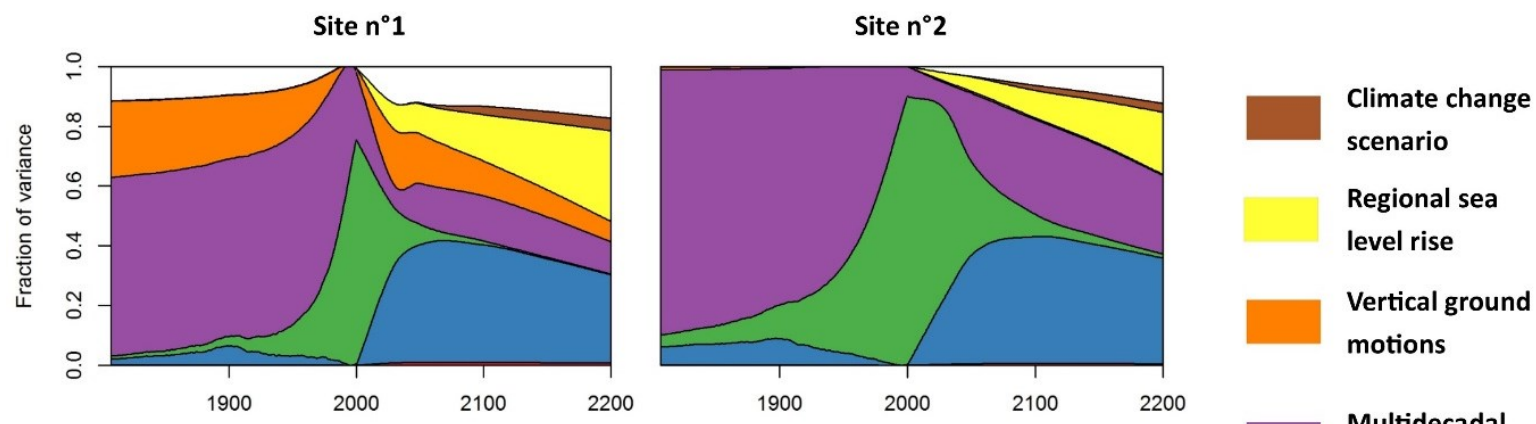

motions

Multidecadal

trend
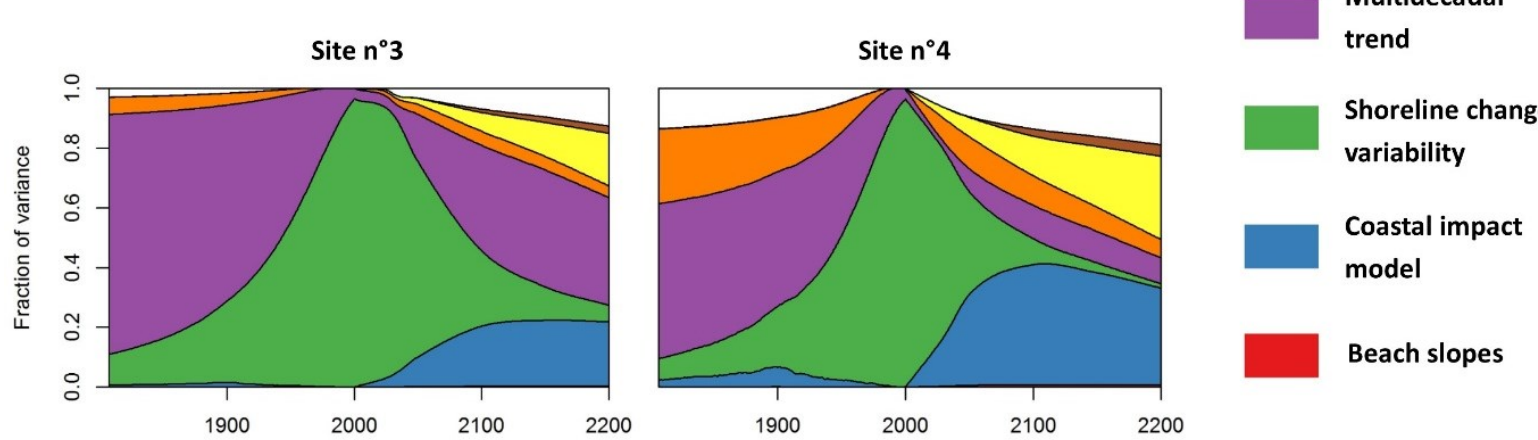

Figure 4: Variance-based global sensitivity analysis of the shoreline change model response as a function of time, for the 4 selected sites in Aquitaine (see Supplementary Material 1). For each date considered, the curves indicate the fraction of the variance of shoreline change projections that could be removed if input parameters were known (see main text). The effect of interactions between parameters are indicated as well. White areas indicate interactions between parameters, corresponding to shoreline positions which can be only reached if at least two uncertain parameters deviate from their mean (see Methods). The graph reads as follows: for site \#1, by 2200, uncertainties in regional sea level rise projections (yellow) account for approximately 30\% of the variance of shoreline change projections. 


\section{Discussion : residual uncertainties}

2 Shoreline change projections presented here assume that the uncertainties of each input parameter can be described using probability distributions (Supplementary Material 2). The uncertainties of shoreline change projections compare well with those of idealized energetic sandy shorelines exposed to sea level changes close to the global average (Le Cozannet et al., 2016). Note that the majority of the coasts are expected to be affected by sea level changes close to or slightly higher than the global average (Carson et al., 2014). However, in addition to the uncertainties presented in Figure 4, there are additional unknowns due to a lack of confidence in the probability distributions themselves (De Vries and Van de Wal, 2015; Bakker et al., 2017; Stephens et al., 2017). These unknowns are called residual uncertainties hereafter, following the terminology of Robinson et al. (2017). They are listed in Table 1.

Sea level rise projections presented here implicitly assign a very low probability to Antarctic marine ice cliffs instabilities (DeConto and Pollard, 2016), although the probability that such process takes place during the $21^{\text {st }}$ century remains unquantified so far (Kopp et al., 2017). Sea level projections considering marine ice cliffs instabilities are significantly higher than those used in this study, as their median reaches $1.8 \mathrm{~m}$ as early as 2100 (Kopp et al., 2017; Le Bars et al., 2017). Our results reflect the fact that according to the sea level projections of Kopp et al. (2014) and those provided by the IPCC (Church et al., 2013), future sea level rise remains a slow process characterized by a large inertia and involving multi-centennial timescales (Clark et al., 2016). Furthermore, the selection of a particular climate change scenario has little impact to future shoreline positions within the probabilistic framework presented in this study (brown area in Figure 4). This reflects the fact that sea level projections of Kopp et al. (2014) are not differentiated enough according to climate change scenarios to create large differences in shoreline change projections given the uncertainties of other processes (Figure 1). In these projections, the dynamic contribution of ice in Antarctica is largely independent from greenhouse gas emissions due to the lack of understanding of processes taking place today (Ritz et al., 2015). However, sea level rise will continue for millennia even if we keep climate warming below the target of the Paris agreement, and the rates of sea level changes over the next centuries will strongly depend on current mitigation policies (Clark et al., 2016; Rockström et al., 2017). Therefore, replacing the current reference 
1 projections (IPCC, 2013; Kopp et al., 2014) by those derived from DeConto and Pollard (2016) would

2 change current coastal impact assessments (Kopp et al., 2017; Le Bars et al., 2017), so that this residual

3 source of uncertainty would deserve specific attention from an adaptation perspective.

$4 \quad$ Table 1: residual uncertainties of probabilistic shoreline change projections

\begin{tabular}{|c|c|c|}
\hline Source of uncertainty & $\begin{array}{l}\text { Uncertainties quantification in } \\
\text { this study }\end{array}$ & $\begin{array}{l}\text { Residual uncertainties (not } \\
\text { quantified in this study) }\end{array}$ \\
\hline Future sea level rise & $\begin{array}{l}\text { Probabilistic regional sea level } \\
\text { rise projections (Kopp et al., } \\
\text { 2014) }\end{array}$ & $\begin{array}{l}\text { Possibility of rapid melting of ice- } \\
\text { sheets (DeConto and Pollard, 2016; } \\
\text { Wong et al., 2017) }\end{array}$ \\
\hline Vertical ground motions & $\begin{array}{l}\text { Geodetic uncertainties at the } \\
\text { permanent GNSS at Cap Ferret } \\
\text { (Santamaria-Gomez et al., 2017) }\end{array}$ & $\begin{array}{l}\text { Representativeness of the GNSS } \\
\text { records (linear extrapolations in } \\
\text { time and space) }\end{array}$ \\
\hline Shoreline change & Seasonal, interannual and & Possible alteration of natural \\
\hline variability and trends & multidecadal $(\sim 50$ years $)$ & $\begin{array}{l}\text { variability modes and or self- } \\
\text { organized patterns (Coco and } \\
\text { Murray 2007) }\end{array}$ \\
\hline Shoreline evolution & Modeling uncertainties & Limited confidence in both \\
\hline modeling framework & $\begin{array}{l}\text { ( } 2 \text { different modeling } \\
\text { approaches) }\end{array}$ & modeling frameworks \\
\hline
\end{tabular}

5

6 Vertical land motions are subject to large residual uncertainties as well: indeed, the analysis of eleven 7 years of continuously recording GNSS data at Cap Ferret suggests that site \#2 is affected by a subsidence 8 of $-1.2 \pm 0.6 \mathrm{~mm} / \mathrm{yr}$ (Santamaria-Gomez et al., 2017), which is qualitatively in agreement with the 9 independent estimate from supplementary levelling data (Source: Aquitaine Coastal Observatory). 10 However, it is unsure that the pointwise information of the permanent GNSS station located at Cap 11 Ferret is representative of the nearby area. Furthermore, current modes of shoreline change variability could be altered by climate change (Charles et al., 2012; Vousdoukas et al., 2016). However, climate 
change models do not indicate that a modification of storm patterns (intensity, trajectories) should be expected in the Bay of Biscay, so that the impacts on wave regimes and surges are expected to remain small compared to those of sea level rise. Nevertheless, rare events such as the unusual 2013/2014 sequence of winter storms suggest that more research is needed in this area (Castelle et al., 2015; Masselink et al., 2016). Finally, coastal impact models uncertainties are quantified here using the differences between two well-established models. However, there is no guarantee that this metrics is appropriate to appraise the real variability of possible impacts of sea level rise on sandy shorelines.

\section{Conclusion}

Despite these uncertainties, our results show that coastal managers in charge of identifying and implementing appropriate adaptation decisions on sandy beaches need to consider uncertainties of sea level rise together with those of coastal impact models. This statement is especially valid at multidecadal to centennial timescales, which are the most relevant for land use planning. Hence, our results call for more research in the area of coastal impact models in order to support coastal adaptation. Over the past decades, sea level rise has been accelerating (Dieng et al., 2017; Chen et al., 2017), and a further acceleration is expected to take place without mitigation of climate change. At the same time, coastal evolution modeling is progressing toward appropriate complexity approaches assimilating coastal observations (e.g., French et al., 2016; Vitousek et al., 2017b). We speculate that the impacts of sea level rise on sandy shorelines should be increasingly observable in the coming decades, so that global, long term, repeated, accurate and precise observations of shoreline positions will be especially relevant to support the development of more trustworthy coastal impact models (Cazenave et al., 2017). 


\section{Methods}

\subsection{Sea level reconstructions and projections}

Sea level projections are those of Kopp et al. (2014) (Figure 1). These projections provide the probability of future sea level rise at La Rochelle. By analyzing tide gauge records, Kopp et al. (2014) estimate a subsidence at La Rochelle to be $-0.55+/-0.52 \mathrm{~mm} / \mathrm{yr}$. However, this subsidence is within the error bars. Consequently, the null hypothesis of a stable location can not be ruled out at the $95 \%$ confidence level. Furthermore, the permanent GNSS station co-located with the La Rochelle tide gauge indicates that the tide gauge is stable too (Santamaria-Gomez et al., 2017). Hence, we removed the subsidence estimation in the projections of Kopp et al., (2014). We assume that the probabilistic sea level rise projections at La Rochelle are applicable in Aquitaine once corrected from the local vertical ground motions.

To reconstruct past sea levels in the Bay of Biscay, we averaged yearly records of 15 stations available in the Permanent Service for Mean Sea Level (PSMSL) corrected for local vertical land motions. We rejected 5 additional stations because they displayed anomalous trends (Pointe Saint Gildas, Le Verdon, Pasajes, Santander 2 and Gijon 2). For each station, the local rates of sea level rise and their uncertainties were computed using a forward-backward Kalman filter (Corriou, 2010; Visser et al., 2015). Local vertical land motions were obtained either using permanent GNSS stations from the SONEL database (Santamaria-Gomez et al., 2017), or, in the absence of GNSS station, using global isostatic adjustment models (Peltier, 2004) available at tide gauge in Jevrejeva et al. (2006). Where no GNSS information was available, where the GNSS station was located too far from the tide gauge, or where the GNSS records displayed large step discontinuities or a clear non-linear behavior, we assigned a Gaussian uncertainty of $2 \mathrm{~mm} / \mathrm{yr}$ (1-sigma) to the vertical land motion value, as obtained from the histogram frequency distribution of all trends in the SONEL database corrected from the global isostatic adjustment. Note that larger subsidence or uplift values would be detectable in the tide gauge sea level time series. Finally, we computed past mean sea levels and their uncertainties using a weighted least square regression. The method used here assumes that vertical land motions are linear over the timescales considered, and that all stations measure the same signal of mean sea level in the Bay of Biscay. 
$8 \Delta S_{s l r}=\frac{\Delta \xi}{\tan (\alpha)}$

We assume that vertical land motions at the site \#2 are those measured by the GNSS station of the CapFerret. In other sites, as no permanent GNSS with sufficiently long records are available, we modelled the uncertainties due to vertical ground motions through a centered normal distribution with a standard deviation of $2 \mathrm{~mm} / \mathrm{yr}$, as obtained from the histogram analysis of all trends computed from the coastal permanent GNSS stations in the SONEL database (Santamaria-Gomez et al., 2017).

\subsection{Coastal impacts models}

The Bruun rule quantifies the shoreline retreat in response to sea level rise as follows (Bruun, 1962):

where $\Delta \xi$ is the cumulated rise of sea level and $\tan (\alpha)$ is the beach slope from the depth of closure to the top of the upper shoreface, usually close to $1 \%$ (Nicholls, 1998).

We implement a variant of the PCR model adapted to the Aquitaine coast. Following Ranasinghe et al. (2012), we use the Larson et al. (2004) formula to compute sediment losses during storms. Furthermore, we estimate gains at the dune toe under calm weather conditions at $25 \pm 15 \mathrm{~m}^{3} / \mathrm{m} /$ year, based on an analysis of dune profile data of the Aquitaine Coastal Observatory. Finally, we incorporate tides as suggested in Larson et al. (2004). The model inputs are virtual time series of events (surge level, significant wave height, peak period and peak direction, tidal levels, event duration, spacing between events) capturing the statistical dependence between variables, their seasonality and event grouping, which are generated using waves and surges hindcasts (Charles et al., 2012; Paris et al., 2013) (see Supplementary Material 1, section 2).

\subsection{Global sensitivity analysis}

The Variance-Based Sensitivity Analysis (VBSA) quantifies the contribution of input variables and parameters to the variance of the outcomes of a model (Saltelli et al. 2008) (see Chu-Agor et al., 2011; Wong and Keller, 2017, Le Cozannet et al., 2015, 2016 for applications of global sensitivity analysis in the area of coastal impacts of sea level rise). Let us define $f$ as the model computing future shoreline change positions. Considering the $n$-dimensional vector $\boldsymbol{X}$ as a random vector of independent random 
$8 \quad S_{i}=\frac{\operatorname{Var}\left[E\left(Y \mid X_{i}\right)\right]}{\operatorname{Var}\left(Y_{j}\right)}$

variables $X_{i}(\mathrm{i}=1,2, \ldots, n)$ (Table 1$)$, then the output $Y=f(\boldsymbol{X})$ is also a random variable (as a function of a random vector). VBSA determines the part of the total unconditional variance $\operatorname{Var}(Y)$ of the output $Y$ resulting from each input random variable $X_{i}$. The partial and total variances of $Y$ are assessed based on the functional analysis of variance decomposition of $f$ (Sobol' 2001), into summands of increasing dimension (provided that $f$ can be integrated). Each of these terms can be evaluated through multidimensional integrals, which can be approximated through Monte-Carlo-based algorithms.

On this basis, the Sobol' indices (ranging between null and unity) can be defined as:

The first-order indices $S_{\mathrm{i}}$ are referred to as "the main effects of $X_{i}$ " and can be interpreted as the expected proportion of the total variance of the output $Y$ (i.e. representing the uncertainty in $Y$ ) that would be removed if we were able to learn the true value of $X_{\mathrm{i}}$. This index provides a measure of importance (i.e. a sensitivity measure) useful when ranking, in terms of importance, the different input parameters. We use the sequential algorithm of Saltelli et al. 2010, using the R implementation of the Jansen formula (Jansen, 1999; Saltelli et al., 2010), and a total of 200,000 model evaluations per time step, which allows to reduce the errors of the first-order indices below $1 \%$.

\subsection{Surrogate of the PCR model}

Under stable sea levels, the PCR models behaves as follows: depending on the frequency and intensity of storms and on the initial conditions, the shoreline, identified as the dune toe, moves around an equilibrium shoreline position, toward which the PCR model converges after a transitional phase of 20 to 30 years. As sea level rises, high water levels during storms become more frequent and induce a retreat of the dune toe parallel to the slopes of the upper shoreface (Larson et al., 2004), so that sediment blown to the dune by aeolian processes cannot compensate losses and a new equilibrium position is found for the dune toe (Ranasinghe et al. 2012). The Figure provided in Supplementary Material 5 displays this equilibrium response as a function of sea level change rates. It shows that its value is close to the amount of sea level rise divided by the slope of the upper shoreface (See section 3 in Supplementary Material 1). The same equilibrium response is obtained for sea level scenarios following 
step functions or parabolic curves, as in the sea level projections of Kopp et al. (2014). This response, which is here illustrated in the case of site \#2, can be explained by the basic principles of the dune model of Larson et al. (2004), which assume that the dune toe evolves parallel to the upper shoreface (Larson et al., 2004). While other dune evolution models may deliver different responses, the more complex model SBEACH has provided similar responses so far (Ranasinghe et al., 2012).

\section{Authors contributions}

GLC designed the research. GLC, TB, BC, GW, NB and JL analyzed the data and performed simulations. RR, BC, JR, DI and DSM provided expertise on the PCR model implementation in Aquitaine, global sensitivity analysis and residual uncertainties. All analyzed the results and contributed to the paper writing, editing and revisions.

\section{Acknowledgement}

This study was supported by the Climate Change projects of the "Aquitaine Coastal Observatory" and by the Risk Prevention Department of BRGM in Orléans, and additional support from the ECLISEA project (European advances on CLImate services for coasts and SEAs) funded through the ERA4CS framework (European Research Area for Climate Services). BC funded by project SONO (ANR-17CE01-0014) from the Agence Nationale de la Recherche (ANR). The SONEL data assembly center is acknowledged for providing comprehensive access to GNSS data and metadata. We thank Carlos Oliveros, Cyril Mallet, Aurélie Maspataud and Franck Desmazes for useful advices and discussions. We thank Robert Kopp for making his data available.

\section{8. $\quad$ References}

1. Anderson, T. R., Fletcher, C. H., Barbee, M. M., Frazer, L. N., \& Romine, B. M. (2015). Doubling of coastal erosion under rising sea level by mid-century in Hawaii. Natural Hazards, 78(1), 75-103.

2. Bakker, A.M., Louchard, D. and Keller, K., 2017. Sources and implications of deep uncertainties surrounding sea level projections. Climatic Change, 140(3-4), pp.339-347.

3. Bird, E.C.F., 1985. Coastline Changes. A Global Review. Wiley, New York, (219 pp.). 
4. Bruun, P. (1962). Sea level rise as a cause of shore erosion. Journal of the Waterways and Harbors division, 88(1), 117-132.

5. Carson, M., Köhl, A., Stammer, D., Slangen, A. B. A., Katsman, C. A., Van de Wal, R. S. W., ... \& White, N. (2016). Coastal sea level changes, observed and projected during the 20th and 21 st century. Climatic Change, 134(1-2), 269-281.

6. Castelle, B., Guillot, B., Marieu, V., Chaumillon, E., Hanquiez, V., Bujan, S., \& Poppeschi, C. (2018). Spatial and temporal patterns of shoreline change of a 280-km high-energy disrupted sandy coast from 1950 to 2014: SW France. Estuarine, Coastal and Shelf Science, 200, 212223.

7. Castelle, B., Marieu, V., Bujan, S., Splinter, K. D., Robinet, A., Sénéchal, N., et al. (2015). Impact of the winter 2013-2014 series of severe western europe storms on a double-barred sandy coast: Beach and dune erosion and megacusp embayments. Geomorphology 238, 135148. doi: 10.1016/j.geomorph.2015.03.006

8. Cazenave A., Le Cozannet G., 2014. Sea level rise and its coastal impacts. Earth's Future, 2(2), 15-34.

9. Cazenave, A., G. Le Cozannet, J. Benveniste, P. L. Woodworth, and N. Champollion (2017), Monitoring coastal zone changes from space, Eos, 98, https://doi.org/10.1029/2017EO085581.

10. Charles, E., Idier, D., Delecluse, P., Déqué, M., \& Le Cozannet, G. (2012). Climate change impact on waves in the Bay of Biscay, France. Ocean Dynamics, 62(6), 831-848.

11. Chen, X., Zhang, X., Church, J. A., Watson, C. S., King, M. A., Monselesan, D., ... \& Harig, C. (2017). The increasing rate of global mean sea level rise during 1993-2014. Nature Climate Change, 7(7), 492.

12. Chu-Agor, M.L., Muñoz-Carpena, R., Kiker, G., Emanuelsson, A. and Linkov, I., 2011. Exploring vulnerability of coastal habitats to sea level rise through global sensitivity and uncertainty analyses. Environmental Modelling \& Software, 26(5), pp.593-604.

13. Church, J. A., \& White, N. J. (2006). A 20th century acceleration in global sea-level rise. Geophysical research letters, 33(1). 
14. Church, J.A., P.U. Clark, A. Cazenave, J.M. Gregory, S. Jevrejeva, A. Levermann, M.A. Merrifield, G.A. Milne, R.S. Nerem, P.D. Nunn, A.J. Payne, W.T. Pfeffer, D. Stammer and A.S. Unnikrishnan, 2013: Sea Level Change. In: Climate Change 2013: The Physical Science Basis. Contribution of Working Group I to the Fifth Assessment Report of the Intergovernmental Panel on Climate Change [Stocker, T.F., D. Qin, G.-K. Plattner, M. Tignor, S.K. Allen, J. Boschung, A. Nauels, Y. Xia, V. Bex and P.M. Midgley (eds.)]. Cambridge University Press, Cambridge, United Kingdom and New York, NY, USA, pp. 1137-1216, doi:10.1017/ CBO9781107415324.026.

15. Clark, P.U., Shakun, J.D., Marcott, S.A., Mix, A.C., Eby, M., Kulp, S., Levermann, A., Milne, G.A., Pfister, P.L., Santer, B.D. and Schrag, D.P., 2016. Consequences of twenty-first-century policy for multi-millennial climate and sea-level change. Nature Climate Change, 6(4), p.360.

16. Coco G. \& Murray B. (2007) Patterns in the sand: From forcing templates to self-organization, Geomorphology, Volume 91, Issues 3-4, 1 November 2007, Pages 271-290, doi:10.1016/j.geomorph.2007.04.023.

17. Cooper, J. A. G., \& Pilkey, O. H. (2004). Sea level rise and shoreline retreat: time to abandon the Bruun Rule. Global and planetary change, 43(3), 157-171.

18. Corriou, J. P. (2012). Commande des procédés (pp. 1-766). Lavoisier, Tec.\\& Doc..

19. Cowell, P. J., Stive, M. J., Niedoroda, A. W., Swift, D. J., de Vriend, H. J., Buijsman, M. C., et al. (2003). The coastal-tract (part 2): applications of aggregated modeling of lower-order coastal change. J. Coast. Res. 19, 828-848.

20. Cowell, P. J., Thom, B. G., Jones, R. A., Everts, C. H., \& Simanovic, D. (2006). Management of uncertainty in predicting climate-change impacts on beaches. Journal of Coastal Research, $232-245$.

21. Dangendorf, S., Marcos, M., Wöppelmann, G., Conrad, C. P., Frederikse, T., \& Riva, R. (2017). Reassessment of 20th century global mean sea level rise. Proceedings of the National Academy of Sciences, 201616007.

22. Davidson-Arnott, R. G. (2005). Conceptual model of the effects of sea level rise on sandy coasts. Journal of Coastal Research, 1166-1172. 
23. de Vries, H. and van de Wal, R.S., 2015. How to interpret expert judgment assessments of 21 st century sea level rise. Climatic Change, 130(2), pp.87-100.

24. De Winter, R.C. and Ruessink, B.G., 2017. Sensitivity analysis of climate change impacts on dune erosion: case study for the Dutch Holland coast. Climatic Change, 141(4), pp.685-701.

25. DeConto, R. M., \& Pollard, D. (2016). Contribution of Antarctica to past and future sea level rise. Nature, 531(7596), 591-597.

26. Dieng, H. B., Cazenave, A., Meyssignac, B., \& Ablain, M. (2017). New estimate of the current rate of sea level rise from a sea level budget approach. Geophysical Research Letters, 44(8), $3744-3751$

27. Enríquez, A.R., Marcos, M., Álvarez-Ellacuría, A., Orfila, A. and Gomis, D., 2017. Changes in beach shoreline due to sea level rise and waves under climate change scenarios: application to the Balearic Islands (western Mediterranean). Natural Hazards and Earth System Sciences, 17(7), p.1075.

28. French, J.; Payo, A.; Murray, B.; Orford, J.; Eliot, M.; Cowell, P. Appropriate complexity for the prediction of coastal and estuarine geomorphic behaviour at decadal to centennial scales. Geomorphology 2016, 256, 3-16.

29. Hallegatte, S., Green, C., Nicholls, R. J., \& Corfee-Morlot, J. (2013). Future flood losses in major coastal cities. Nature climate change, 3(9), 802.

30. Hinkel, J., Jaeger, C., Nicholls, R. J., Lowe, J., Renn, O., \& Peijun, S. (2015). Sea level rise scenarios and coastal risk management. Nature Climate Change, 5(3), 188.

31. Hinkel, J., Lincke, D., Vafeidis, A. T., Perrette, M., Nicholls, R. J., Tol, R. S., ... \& Levermann, A. (2014). Coastal flood damage and adaptation costs under 21 st century sea level rise. Proceedings of the National Academy of Sciences, 111(9), 3292-3297.

32. Hinkel, J., Nicholls, R. J., Tol, R. S., Wang, Z. B., Hamilton, J. M., Boot, G., ... \& Klein, R. J. (2013). A global analysis of erosion of sandy beaches and sea level rise: An application of DIVA. Global and Planetary change, 111, 150-158.

33. Jansen, M. J. (1999). Analysis of variance designs for model output. Computer Physics Communications, 117(1-2), 35-43. 
34. Jevrejeva, S., Grinsted, A., Moore, J. C., \& Holgate, S. (2006). Nonlinear trends and multiyear cycles in sea level records. Journal of Geophysical Research: Oceans, 111(C9).

35. Jiménez, J.A., Valdemoro, H.I., Bosom, E., Sánchez-Arcilla, A. and Nicholls, R.J., 2017. Impacts of sea level rise-induced erosion on the Catalan coast. Regional environmental change, 17(2), pp.593-603

36. Kopp, R. E., DeConto, R. M., Bader, D. A., Hay, C. C., Horton, R. M., Kulp, S., ... \& Strauss, B. H. (2017). Evolving Understanding of Antarctic Ice-Sheet Physics and Ambiguity in Probabilistic Sea-Level Projections. Earth's Future.

37. Kopp, R. E., Horton, R. M., Little, C. M., Mitrovica, J. X., Oppenheimer, M., Rasmussen, D. J., ... \& Tebaldi, C. (2014). Probabilistic 21st and 22nd century sea-level projections at a global network of tide-gauge sites. Earth's Future, 2(8), 383-406.

38. Larson, M., Erikson, L., \& Hanson, H. (2004). An analytical model to predict dune erosion due to wave impact. Coastal Engineering, 51(8), 675-696.

39. Le Bars, D., Drijfhout, S., \& de Vries, H. (2017). A high-end sea level rise probabilistic projection including rapid Antarctic ice sheet mass loss. Environmental Research Letters, 12(4), 044013.

40. Le Cozannet, G., Garcin, M., Yates, M., Idier, D., \& Meyssignac, B. (2014). Approaches to evaluate the recent impacts of sea level rise on shoreline changes. Earth-science reviews, 138, 47-60.

41. Le Cozannet, G., Oliveros, C., Castelle, B., Garcin, M., Idier, D., Pedreros, R., \& Rohmer, J. (2016). Uncertainties in sandy shorelines evolution under the Bruun rule assumption. Frontiers in Marine Science, 3, 49.

42. Le Cozannet, G., Rohmer, J., Cazenave, A., Idier, D., van De Wal, R., De Winter, R., Pedreros, R., Balouin, Y., Vinchon, C. and Oliveros, C., 2015. Evaluating uncertainties of future marine flooding occurrence as sea level rises. Environmental Modelling \& Software, 73, pp.44-56.

43. Leatherman, Stephen P., Keqi Zhang, and Bruce C. Douglas. "Sea level rise shown to drive coastal erosion." Eos, Transactions American Geophysical Union 81.6 (2000): 55-57. 
44. Li, F., Van Gelder, P. H. A. J. M., Ranasinghe, R., Callaghan, D. P., \& Jongejan, R. B. (2014). Probabilistic modelling of extreme storms along the Dutch coast. Coastal Engineering, 86, 113.

45. Luijendijk, A., Hagenaars, G., Ranasinghe, R., Baart, F., Donchyts, G. and Aarninkhof, S., 2018. The State of the World's Beaches. Scientific reports, 8 .

46. Magnan, A. K., Schipper, E. L. F., Burkett, M., Bharwani, S., Burton, I., Eriksen, S., ... \& Ziervogel, G. (2016). Addressing the risk of maladaptation to climate change. Wiley Interdisciplinary Reviews: Climate Change, 7(5), 646-665.

47. Masselink, G., Castelle, B., Scott, T., Dodet, G., Suanez, S., Jackson, D., Floc'h, F., 2016. Extreme wave activity during 2013/2014 winter and morphological impacts along the Atlantic coast of Europe, Geophys. Res. Lett., 43, 2135-2143. doi:10.1002/2015GL067492.

48. Mastrandrea M, Field C B, Stocker T F, Edenhofer O, Ebi K L, Frame D J and Plattner G K 2010 Guidance Note for Lead Authors of the IPCC 5th Assessment Report on Consistent Treatment of Uncertainties

49. Moftakhari, H.R., Salvadori, G., AghaKouchak, A., Sanders, B.F. and Matthew, R.A., 2017. Compounding effects of sea level rise and fluvial flooding. Proceedings of the National Academy of Sciences, 114(37), pp.9785-9790.

50. Nicholls, R. J. (1998). Assessing erosion of sandy beaches due to sea level rise. Geological Society, London, Engineering Geology Special Publications, 15(1), 71-76.

51. Nicholls, R. J., \& Cazenave, A. (2010). Sea level rise and its impact on coastal zones. science, 328(5985), 1517-1520.

52. Paris, F., T. Bulteau, T., Pedreros, R., Oliveros, C., Mugica, J. (2013), Simulations rétrospectives (1979-2009) des surcotes-décotes dans le Golfe de Gascogne. $1^{\text {ère }}$ édition des Journées REFMAR les 18-19juin 2013, Paris.

53. Peltier, W. R. (2004). Global glacial isostasy and the surface of the ice-age Earth: the ICE-5G (VM2) model and GRACE. Annu. Rev. Earth Planet. Sci., 32, 111-149. 
54. Ranasinghe, R. (2016). Assessing climate change impacts on open sandy coasts: A review. Earth-science reviews, 160, 320-332.

55. Ranasinghe, R., \& Stive, M. J. (2009). Rising seas and retreating coastlines. Climatic Change, 97(3), 465-468.

56. Ranasinghe, R., Callaghan, D., \& Stive, M. J. (2012). Estimating coastal recession due to sea level rise: beyond the Bruun rule. Climatic Change, 110(3), 561-574.

57. Ritz, C., Edwards, T. L., Durand, G., Payne, A. J., Peyaud, V., \& Hindmarsh, R. C. (2015). Potential sea level rise from Antarctic ice-sheet instability constrained by observations. Nature, 528(7580), 115-118.

58. Robinson, A.E.; Ogunyoye, F.; Sayers, P.; van den Brink, T.; Tarrant, O. (2017). Accounting for Residual Uncertainty: Updating the Freeboard Guide. Report-SC120014, UK Environmental Agency, Flood and Coastal Erosion Risk Management Research and Development Programme. Available online: https://www.gov.uk/government/uploads/system/uploads/attachment data/file/595618/Accoun ting for residual uncertainty an update to the fluvial freeboard guide - report.pdf (accessed on 6 May 2017).

59. Rockström, J., Gaffney, O., Rogelj, J., Meinshausen, M., Nakicenovic, N., \& Schellnhuber, H. J. (2017). A roadmap for rapid decarbonization. Science, 355(6331), 1269-1271.

60. Saltelli, A., Annoni, P., Azzini, I., Campolongo, F., Ratto, M., \& Tarantola, S. (2010). Variance based sensitivity analysis of model output. Design and estimator for the total sensitivity index. Computer Physics Communications, 181(2), 259-270.

61. Saltelli, A., Ratto, M., Andres, T., Campolongo, F., Cariboni, J., Gatelli, D., ... \& Tarantola, S. (2008). Global sensitivity analysis: the primer. John Wiley \& Sons.

62. Santamaria-Gomez, A., Gravelle, M., Dangendord, S., Marcos, M., Spada, G., Wöppelmann, G. (2017). Uncertainty of the 20th century sea level rise due to vertical land motion errors. Earth and Planetary Science Letters, 473, 24-32.

63. Sobol, I. M. (2001). Global sensitivity indices for nonlinear mathematical models and their Monte Carlo estimates. Mathematics and computers in simulation, 55(1), 271-280. 
64. Stammer D., Cazenave A., Ponte R. M., Tamisiea M. E. (2013) - Causes for contemporary regional sea level changes. Annual review of marine science, vol. 5, doi: 10.1146/annurevmarine-121211-172406, p. 21-46, ISSN 1941-1405.

65. Stephens, Scott A., Robert G. Bell, and Judy Lawrence. "Applying principles of uncertainty within coastal hazard assessments to better support coastal adaptation." Journal of Marine Science and Engineering 5.3 (2017): 40.

66. Stive, Marcel JF. "How important is global warming for coastal erosion?." Climatic Change 64.1-2 (2004): 27-39.

67. Sweet, W. V., \& Park, J. (2014). From the extreme to the mean: Acceleration and tipping points of coastal inundation from sea level rise. Earth's Future, 2(12), 579-600.

68. Toimil, A., Losada, I. J., Camus, P., \& Díaz-Simal, P. (2017). Managing coastal erosion under climate change at the regional scale. Coastal Engineering, 128, 106-122.

69. Visser, H., Dangendorf, S., \& Petersen, A. C. (2015). A review of trend models applied to sea level data with reference to the "acceleration-deceleration debate". Journal of Geophysical Research: Oceans.

70. Vitousek, S., Barnard, P. L., \& Limber, P. (2017b). Can beaches survive climate change?. Journal of Geophysical Research: Earth Surface, 122(4), 1060-1067.

71. Vitousek, S., Barnard, P. L., Fletcher, C. H., Frazer, N., Erikson, L., \& Storlazzi, C. D. (2017a). Doubling of coastal flooding frequency within decades due to sea level rise. Scientific reports, 7(1), 1399.

72. Vousdoukas, M. I., Voukouvalas, E., Annunziato, A., Giardino, A., \& Feyen, L. (2016). Projections of extreme storm surge levels along Europe. Climate Dynamics, 47(9-10), 31713190.

73. Wahl, T., Haigh, I. D., Nicholls, R. J., Arns, A., Dangendorf, S., Hinkel, J., \& Slangen, A. B. A. (2017). Understanding extreme sea levels for broad-scale coastal impact and adaptation analysis. Nature Communications, 8 , ncomms16075.

74. Wainwright, D. J., Ranasinghe, R., Callaghan, D. P., Woodroffe, C. D., Jongejan, R., Dougherty, A. J., ... \& Cowell, P. J. (2015). Moving from deterministic towards probabilistic 
coastal hazard and risk assessment: Development of a modelling framework and application to Narrabeen Beach, New South Wales, Australia. Coastal engineering, 96, 92-99.

75. Wong, T.E. and Keller, K., 2017. Deep Uncertainty Surrounding Coastal Flood Risk Projections: A Case Study for New Orleans. Earth's Future, 5(10), pp.1015-1026.

76. Wong, Tony E., Alexander MR Bakker, and Klaus Keller. "Impacts of Antarctic fast dynamics on sea level projections and coastal flood defense." Climatic Change 144.2 (2017): 347-364.

77. Woodworth, P. L., Menéndez, M., \& Gehrels, W. R. (2011). Evidence for century-timescale acceleration in mean sea levels and for recent changes in extreme sea levels. Surveys in geophysics, 32(4-5), 603-618.

78. Wöppelmann, G., Marcos, M. (2016) Vertical land motion as a key to understanding sea level change and variability. Reviews of Geophysics, 54, 64-92 


\section{Coastal settings}

The approach is applied to the open ocean beaches of the French Aquitaine coast (Bay of Biscay). This sandy coast is $230 \mathrm{~km}$ long, sparsely urbanized, and constituted by high-energy meso-macrotidal open beaches which are backed by high (generally 15 to $20 \mathrm{~m}$ ) and wide (generally larger than $100 \mathrm{~m}$ ) coastal dunes. Topographic transects of the beach-dune systems are annually monitored with cm-level precision surveys using differential kinematic Global Positioning System (GPS) since 2008 over more than 20 transects (Bulteau et al., 2014), providing useful data to analyze inter-annual variations of the beachdune system (dune nourishment by aeolian processes, slopes of the upper shoreface). Furthermore, an analysis of past shoreline positions based on remote sensing images allows to analyze shoreline variability and trends at different timescales (Supplementary Material 4; Castelle et al., 2018). Panels B and C in Supplementary Material 4 show that the estimation of multi-decadal trends and variability of shoreline positions are mostly insensitive to the removal of the least reliable shoreline position (1950), suggesting that the evaluation of shoreline change variability and trends are robust against outliers and missing shoreline data. Hence, owing to these observations, a probability distribution can be proposed to represent the uncertainties of the different processes contributing to shoreline changes included in equation (1) (Supplementary Material 2). Four contrasted sites are selected to perform reconstructions and projections of shoreline positions and to analyze the uncertainties (Supplementary Material 2, 3 and $4)$.

\section{Method used to generate virtual time series of events}

The PCR model requires simulating virtual time series of the following statistically dependent variables: significant wave height Hs, peak period Tp, peak direction $\theta p$, event duration $D$, surge $\eta$, tidal level A, spacing between events G. We used wave data from BoBWA_10kH database (Charles et al., 2012 ; http://bobwa.brgm.fr). The extracted point is located $\left(44.65^{\circ} \mathrm{N} ;-1.45^{\circ} \mathrm{E}\right)$ at $51 \mathrm{~m}$ depth and the covered period is 1958-2002 at hourly time step. Surges and tidal signal come from a reanalysis covering the 
period 1979-2009 at 10 min time step (Paris et al., 2013). The full temporal simulation proceeds in seven steps:

1- Select independent events from original time series of waves and surge. Following the approach of Gouldby et al. (2014) we introduced a notional flooding level based on wave setup calculated with the formula of Stockdon et al. (2006) and surges:

$$
F L=\operatorname{setup}+\eta
$$

A flooding level time series of 23.66 years is thus created. Independent events are then selected using a Peaks-Over-Threshold (POT) approach and appropriate independence temporal criteria (minimum of 1 day between the end of an event and the beginning of the next one, or, if it is not verified, a minimum of 2 days between two consecutive FL peaks). We end up with 473 independent combinations of (Hs, Tp, $\theta p, D, \eta)$

2- Fit extreme value distributions (Generalized Pareto Distributions) to wave height Hs, surge $\eta$ and storm duration $\mathrm{D}$ (marginal distributions).

3- Fit the semi-parametric conditional extreme model of Heffernan and Tawn (2004) to model dependencies between $\mathrm{Hs}, \mathrm{D}$ and $\eta$.

4- Fit a non-homogenous Poisson distribution to the spacing between storms $\mathrm{G}$ taking into account event grouping as in Callaghan et al. (2008) and Luceño et al. (2006).

5- Generate times series of combinations of (Hs, D, $\eta, G)$ representing 100 years by means of a Monte-Carlo procedure.

6- Fit the peak wave period and peak direction conditional distributions (conditioned to Hs) and complete the synthetic dataset with simulations of Tp and $\theta p$. The same models as in Gouldby et al. (2014) are used for Tp and $\theta \mathrm{p}$.

7- Finally, simulate the tidal level A for each synthetic event. To do so, a Saros period (18.6 years) of the tidal signal is duplicated multiple times so that the total length covers the simulated period (100 years). Then, we select the tidal peak closest to each simulated event.

Steps 5 to 7 are repeated multiple times to be able to characterize the uncertainty due to random Monte Carlo simulations. 


\section{Surrogate of the PCR model}

The gray areas in the Figure provided in Supplementary Material 5 show the variability of the PCR model response due to its response to 50 time series of virtual events (see Methods). Dark gray indicates likely shoreline change rates, whose probability is larger than $66 \%$ according to the simulations (consistently with the IPCC language on uncertainties). Light gray areas provide information regarding higher quantiles, displaying the possible values of very likely and virtually certain shoreline change rates according to the PCR simulations. The standard deviation of the shoreline positions obtained with the PCR model is less than $9 \mathrm{~m}$ given a fixed sea level rise step, which is smaller or of the same order than the observed shoreline change variability ( 8 to $20 \mathrm{~m}$ according to the panel $\mathrm{B}$ in the Figure of Supplementary Material 4). This shoreline change variability is included in equation (1) through the term Lvar.

Supplementary Material 5 shows that in a first approximation, the equilibrium response of the PCR model can be emulated by equation (2), where the slopes of the upper shoreface (from 4 to $13 \%$, see Supplementary Material 2) are substituted to the Bruun slopes (from 1.2 to $1.5 \%$ in Aquitaine). Finally, using equation (1) with the Bruun rule or the PCR surrogate model has a negligible computation time, so that it becomes possible to perform a propagation of probabilistic uncertainties and a global sensitivity analysis by means of a quasi-Monte-Carlo procedure.

\section{References of the supplementary material:}

1. Bernon N., Mallet C., Belon, R., Hoareau A., Bulteau T. et Garnier C. (2016), caractérisation de l'aléa recul du trait de côte sur le littoral de la côte aquitaine aux horizons 2025 et 2050. Rapport final. BRGM/RP-66277-FR, 99p., 48 ill., 16 tab., 2 ann. http://infoterre.brgm.fr/rapports/RP-66277-FR.pdf

2. Bulteau T., Mugica J., Mallet C., Garnier C., Rosebery D., Maugard F., Nicolae Lerma A., Nahon A. avec la collaboration de Millescamps B. (2014) - Évaluation de l'impact des tempêtes de l'hiver 2013- 2014 sur la morphologie de la Côte Aquitaine. Rapport final. 
BRGM/RP-63797-FR, 68 p., 138 fig., 8 tab., 2 ann.

http://www.brgm.fr/sites/default/brgm/projets/oca/RP-63797-FR.pdf

3. Callaghan D, Nielsen P, Short A, Ranasinghe R (2008) Statistical simulation of wave climate and extreme beach erosion. Coast Eng 55(5):375-390

4. Gouldby, B., Méndez, F. J., Guanche, Y., Rueda, A., and Mínguez, R.: A methodology for deriving extreme nearshore sea conditions for structural design and flood risk analysis, Coast. Eng., 88, 15-26, 2014.

5. Heffernan, J. E. and Tawn, J. A. «A conditional approach for multivariate extreme values.» Journal of the Royal Statistical Society, 2004: 66, 3, 497-546.

6. Idier, D., Castelle, B., Charles, E., \& Mallet, C. (2013). Longshore sediment flux hindcast: spatio-temporal variability along the SW Atlantic coast of France. Journal of Coastal Research, 65(sp2), 1785-1790.

7. Luceño, A., Menéndez, M., Méndez, F., 2006. The effect of temporal dependence on the estimation of the frequency of extreme ocean climate events. Proceedings of the Royal Society of London, Series A 462 (2070), 1683-1697. 
2 Probabilistic representation of the uncertainties of input parameters in equation (1).

\begin{tabular}{|c|c|c|c|}
\hline Variable & Distribution & Values & Source of information \\
\hline $\begin{array}{l}\text { Beach slope } \\
\text { from the dune } \\
\text { toe to the depth } \\
\text { of closure }\end{array}$ & Uniform & $1.2 \%$ to $1.5 \%$ & $\begin{array}{l}\text { Yearly beach profile surveys (DGPS) of } \\
\text { the Aquitaine Coastal Observatory } \\
\text { (Bernon et al., 2016) }\end{array}$ \\
\hline $\begin{array}{l}\text { Slope of the } \\
\text { upper shoreface } \\
\text { (Larson et al., } \\
\text { 2004) }\end{array}$ & Uniform & $\begin{array}{l}\text { Site \#1 (km 55): } 4 \% \text { to } 10 \% \\
\text { Site \#2 (km 140): } 6 \% \text { to } \\
12 \% \\
\text { Site \#3 (km 165): } 6 \% \text { to } \\
13 \% \\
\text { Site \#4 (km 197) : } 5 \% \text { to } \\
13 \%\end{array}$ & $\begin{array}{l}\text { Yearly beach profile surveys (DGPS) of } \\
\text { the Aquitaine Coastal Observatory } \\
\text { (Bulteau et al., 2014) }\end{array}$ \\
\hline $\begin{array}{l}\text { Coastal impact } \\
\text { model }\end{array}$ & $\begin{array}{l}\text { Discrete } \\
\text { uniform }\end{array}$ & $\begin{array}{l}\text { Bruun or emulation of } \\
\text { Ranasinghe }\end{array}$ & $\begin{array}{l}\text { Bruun (1962) } \\
\text { Ranasinghe et al. (2012) }\end{array}$ \\
\hline $\begin{array}{l}\text { Variability of } \\
\text { shoreline } \\
\text { position at } \\
\text { timescales } \\
\text { ranging from } \\
\text { events to several } \\
\text { decades }\end{array}$ & Gaussian & $\begin{array}{l}\text { Site } 1(\mathrm{~km} \mathrm{55}):+/-3.2 \mathrm{~m} \\
\text { Site } 2(\mathrm{~km} \mathrm{140)}:+/-9.4 \mathrm{~m} \\
\text { Site } 3(\mathrm{~km} \mathrm{165)}:+/-21 \mathrm{~m} \\
\text { Site } 4(\mathrm{~km} \mathrm{197)}:+/-8.5 \mathrm{~m}\end{array}$ & $\begin{array}{l}\text { Based on past observed multi-decadal } \\
\text { shoreline change variability (Castelle et } \\
\text { al., 2018; see Supplementary Material 4). }\end{array}$ \\
\hline $\begin{array}{l}\text { Linear trend of } \\
\text { shoreline } \\
\text { evolution at } \\
\text { longer } \\
\text { timescales }\end{array}$ & Gaussian & $\begin{array}{l}\text { Site } 1: 0.15+/-0.12 \mathrm{~m} / \mathrm{yr} \\
\text { Site } 2:-0.083+/-0.22 \mathrm{~m} / \mathrm{yr} \\
\text { Site } 3: 1.08+/-0.28 \mathrm{~m} / \mathrm{yr} \\
\text { Site } 4: 0.82+/-0.11 \mathrm{~m} / \mathrm{yr}\end{array}$ & $\begin{array}{l}\text { Based on past observed multi-decadal } \\
\text { shoreline change variability (Castelle et } \\
\text { al., 2018; see Supplementary Material 4). }\end{array}$ \\
\hline $\begin{array}{l}\text { Vertical ground } \\
\text { motion }\end{array}$ & Gaussian & $\begin{array}{l}\text { Site } 1: 0+/-2 \mathrm{~mm} / \mathrm{yr} \\
\text { Site } 2:-1,2 \pm 0,6 \mathrm{~mm} / \mathrm{yr} \\
\text { (GNSS) } \\
\text { Site } 3: 0+/-2 \mathrm{~mm} / \mathrm{yr} \\
\text { Site } 4: 0+/-2 \mathrm{~mm} / \mathrm{yr}\end{array}$ & $\begin{array}{l}\text { Based on the permanent GNSS located at } \\
\text { Cap-Ferret (site \#2). For the other sites, no } \\
\text { trend can be computed yet (short records), } \\
\text { and the uncertainties of vertical ground } \\
\text { motion is based on the mean and standard } \\
\text { deviation of all permanent GNSS } \\
\text { velocities in the SONEL database } \\
\text { (Santamaria-Gomez et al., 2017) after } \\
\text { removal of the effects of the global } \\
\text { isostatic adjustment using the ICE-5G } \\
\text { model (Peltier, 2004) (see Methods). }\end{array}$ \\
\hline $\begin{array}{l}\text { Past regional } \\
\text { sea level rise }\end{array}$ & Gaussian & Sea Figure 1 & $\begin{array}{l}\text { Based on a reconstruction of past sea level } \\
\text { in the Bay of Biscay (see Methods) }\end{array}$ \\
\hline $\begin{array}{l}\text { Future regional } \\
\text { sea level rise }\end{array}$ & $\begin{array}{l}\text { Non } \\
\text { parametric } \\
\text { distribution }\end{array}$ & See Figure 1 & $\begin{array}{l}\text { Data of La Rochelle (Kopp et al., 2014), } \\
\text { corrected from vertical ground motions } \\
\text { measured with a permanent GNSS station } \\
\text { (see methods) }\end{array}$ \\
\hline $\begin{array}{l}\text { Climate change } \\
\text { scenario }\end{array}$ & $\begin{array}{l}\text { Discrete } \\
\text { uniform }\end{array}$ & $\mathrm{RCP} 2.6,4.5$ or 8.5 & Kopp et al., 2014; See Figure 1. \\
\hline
\end{tabular}




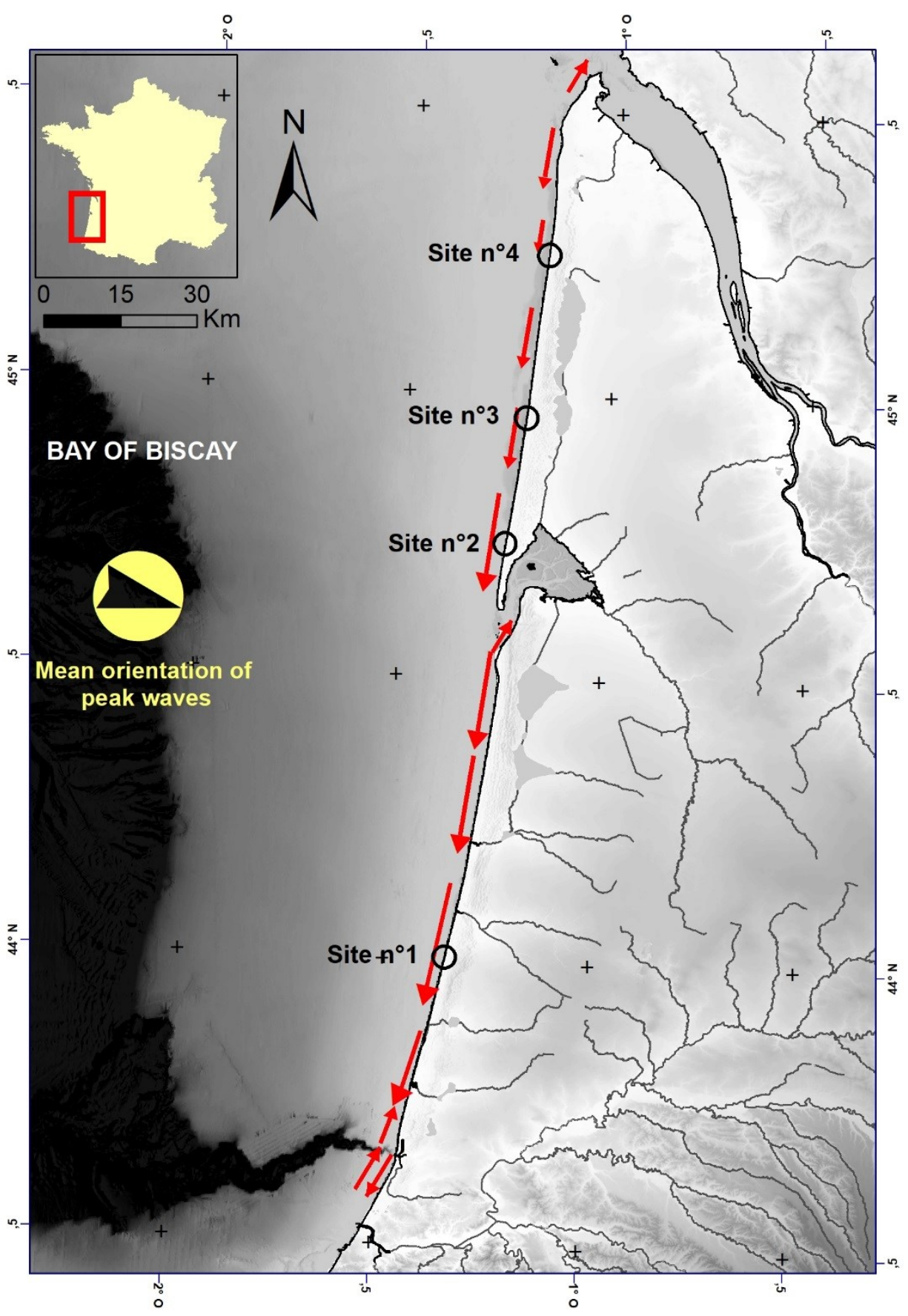

3 Map showing the location of four selected coastal sites in Aquitaine, the mean orientation of peak waves and the longshore sediment fluxes (adapted from Idier et al., 2013). 

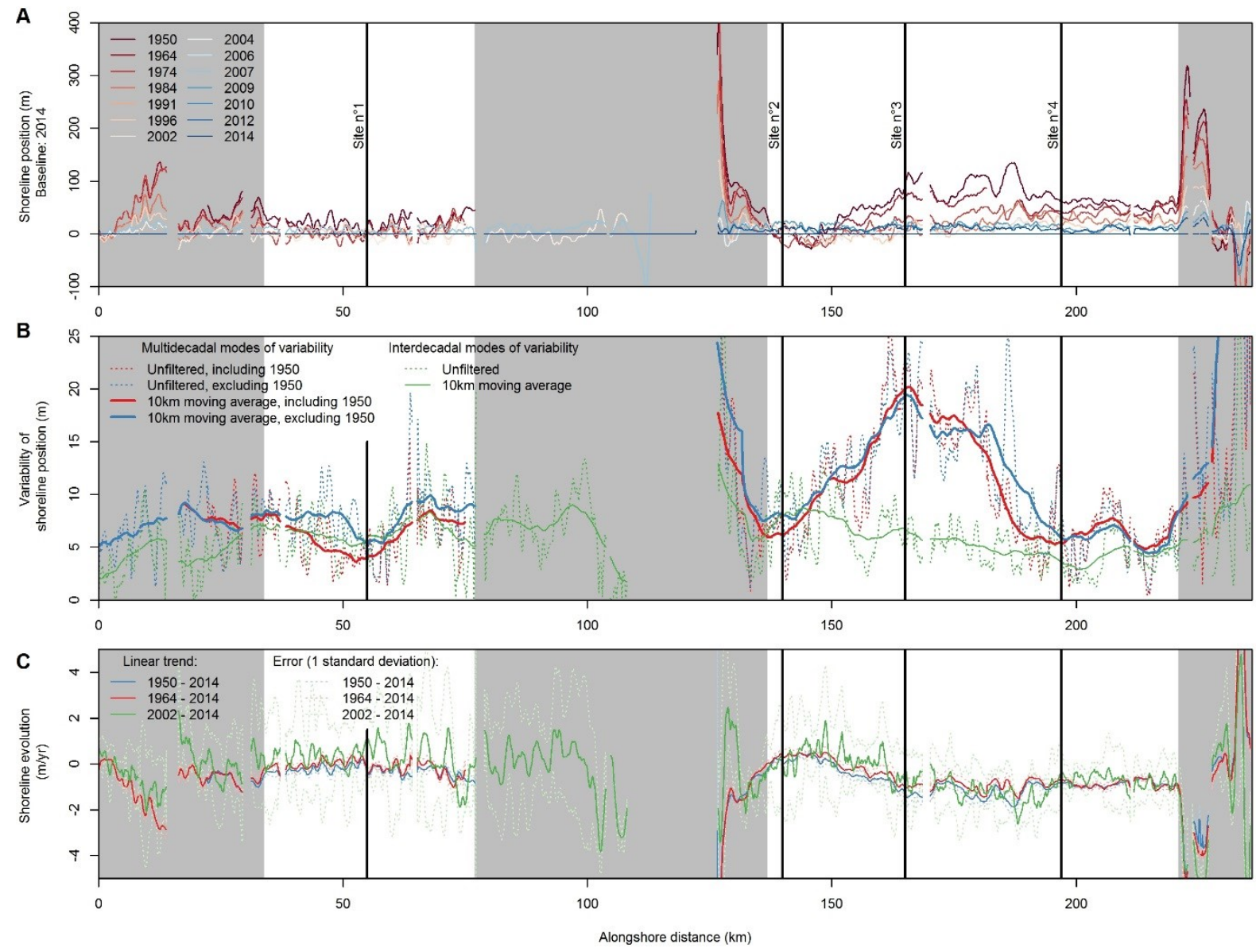

3 Spatial variability of shoreline position (A), shoreline change variability (B) and trends (C) along the

4 sandy shorelines of Aquitaine. In Panel B, shoreline change variability is estimated as the standard

5 deviation of the de-trended shoreline positions for each transect with at least 3 observations over 3

6 different decades (blue and red curves) and using all shoreline positions available from 2002 to 2014

7 (green curves). In areas unaffected by estuarine processes, the average shoreline change variability

8 accounts for $\pm 9.8 \mathrm{~m}$ around the linear multi-decadal trend if all shorelines (including 1950) are included.

9 The grey areas indicate coastal sites excluded from the analysis, either because they are too close from estuaries or because of the lack of shoreline data (Data: Castelle et al., 2018). 


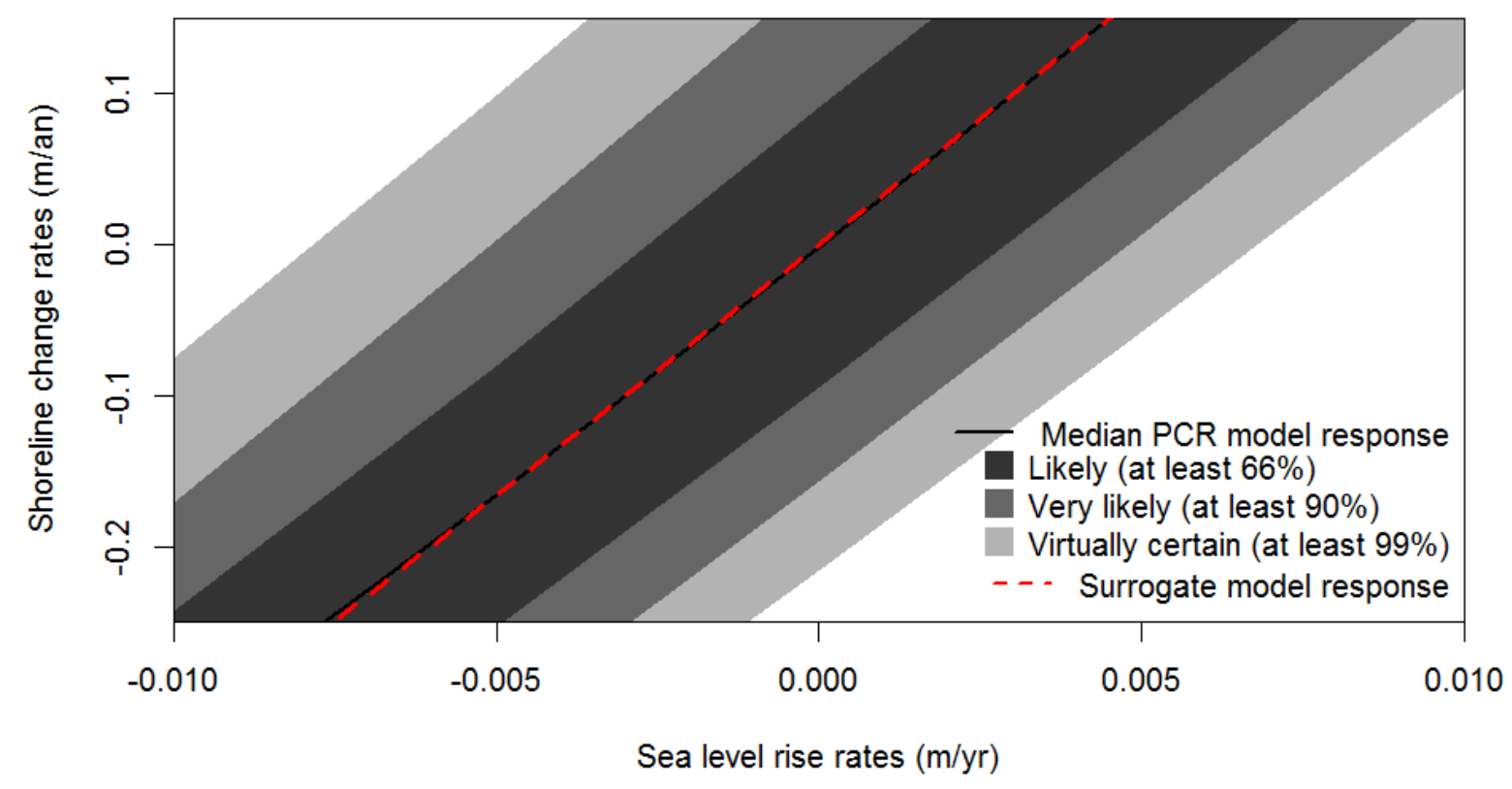

2

3 Shoreline change rates and related uncertainties for values of sea level rise ranging from $-25 \mathrm{~mm} / \mathrm{yr}$ to

$4+15 \mathrm{~mm} / \mathrm{yr}$ using the PCR model and its surrogate to site \#2 (see Methods). Shoreline retreats are

5 computed assuming that the shoreline is at equilibrium at the beginning of the simulations, and that the

6 upper beach slope is equal to 3\%. The uncertainties of shoreline change rates originate from the use of

750 random time series of 100 years of virtual events as well as from the nourishment of the dune between

8 extreme events (see Supplementary Material 1). 
2
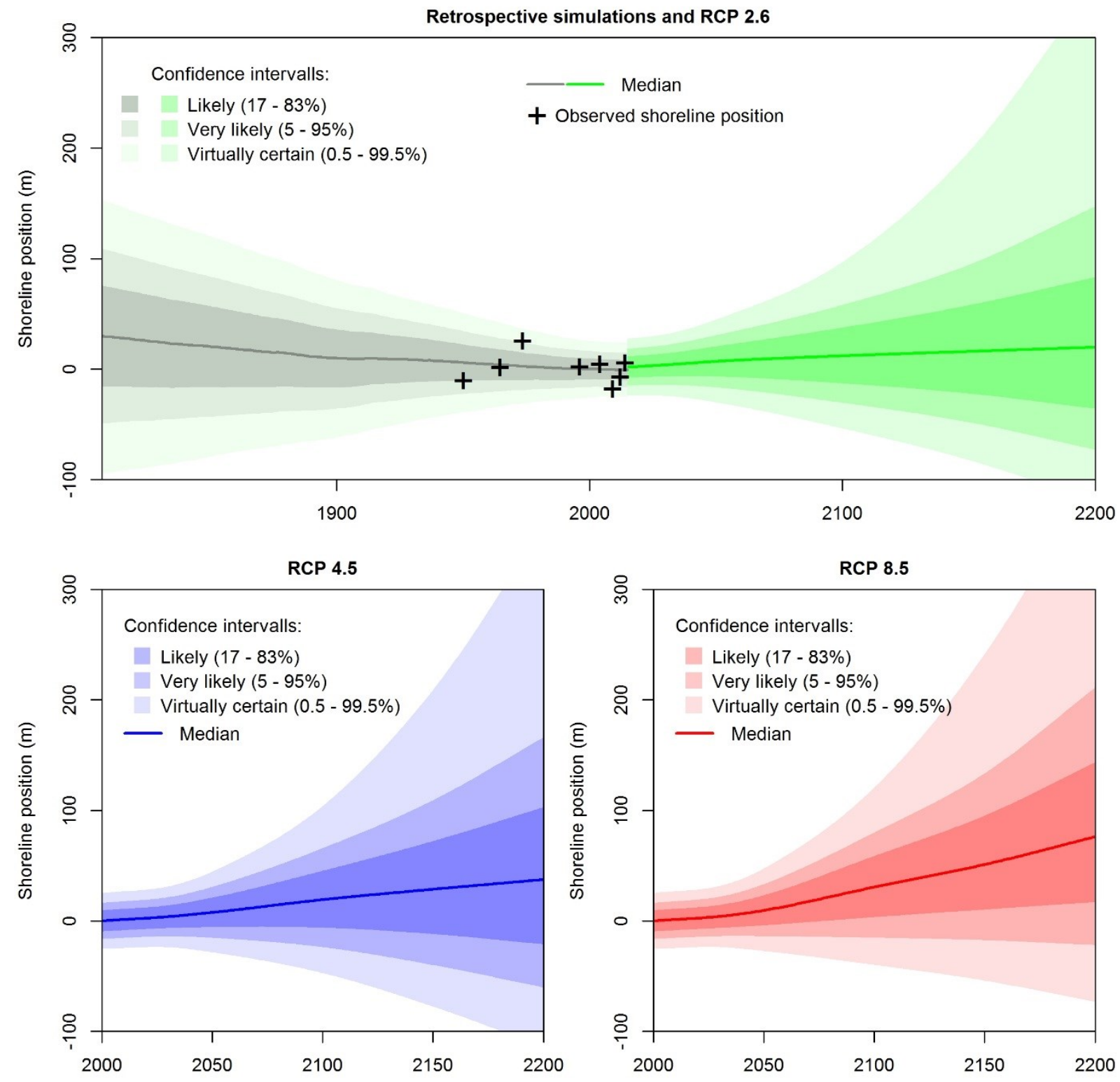

3

4

5 Same as Figure 2, for the site \#2.

6 

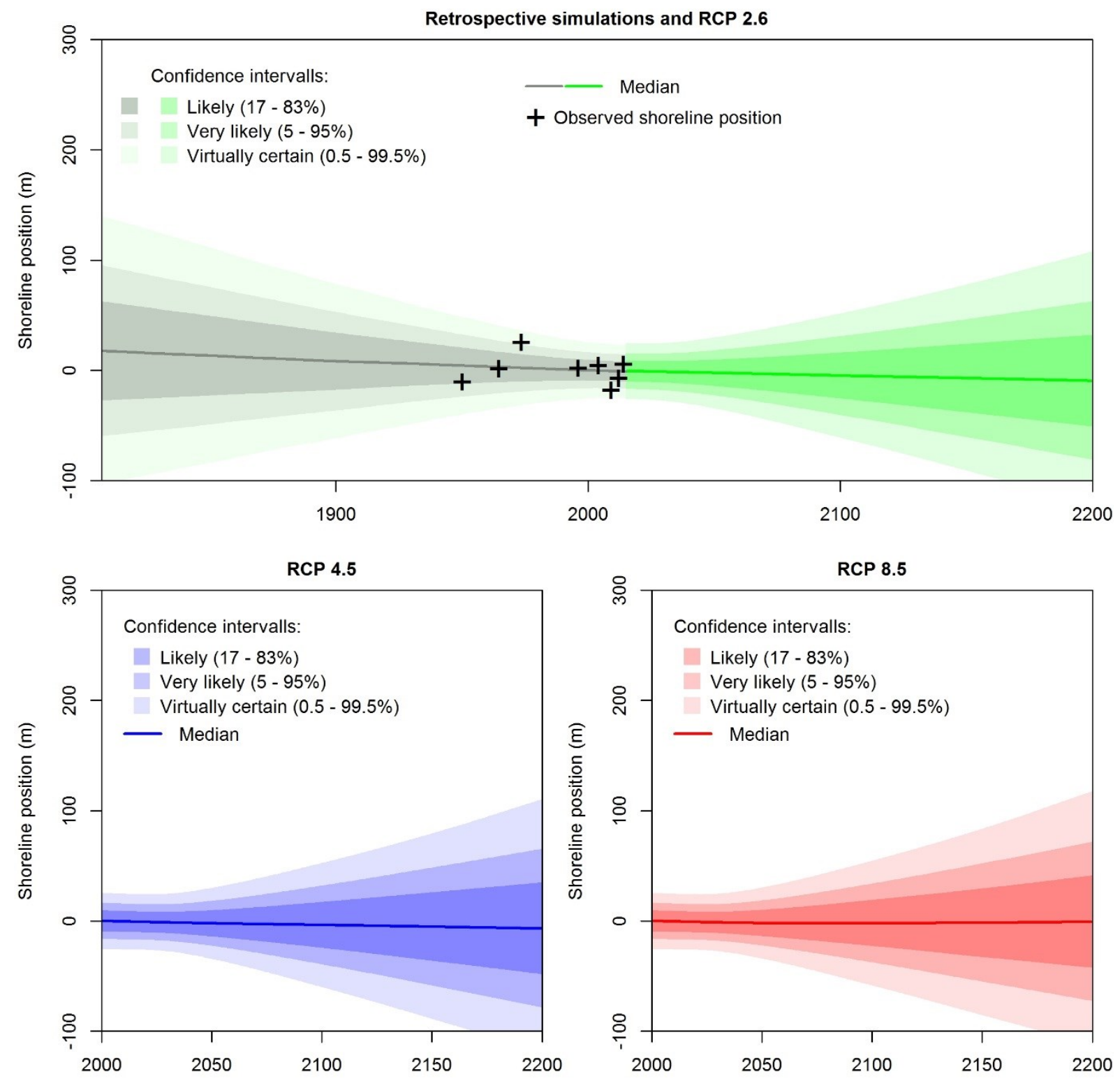

2

3

Same as Figure 3, for the site \#2

4 

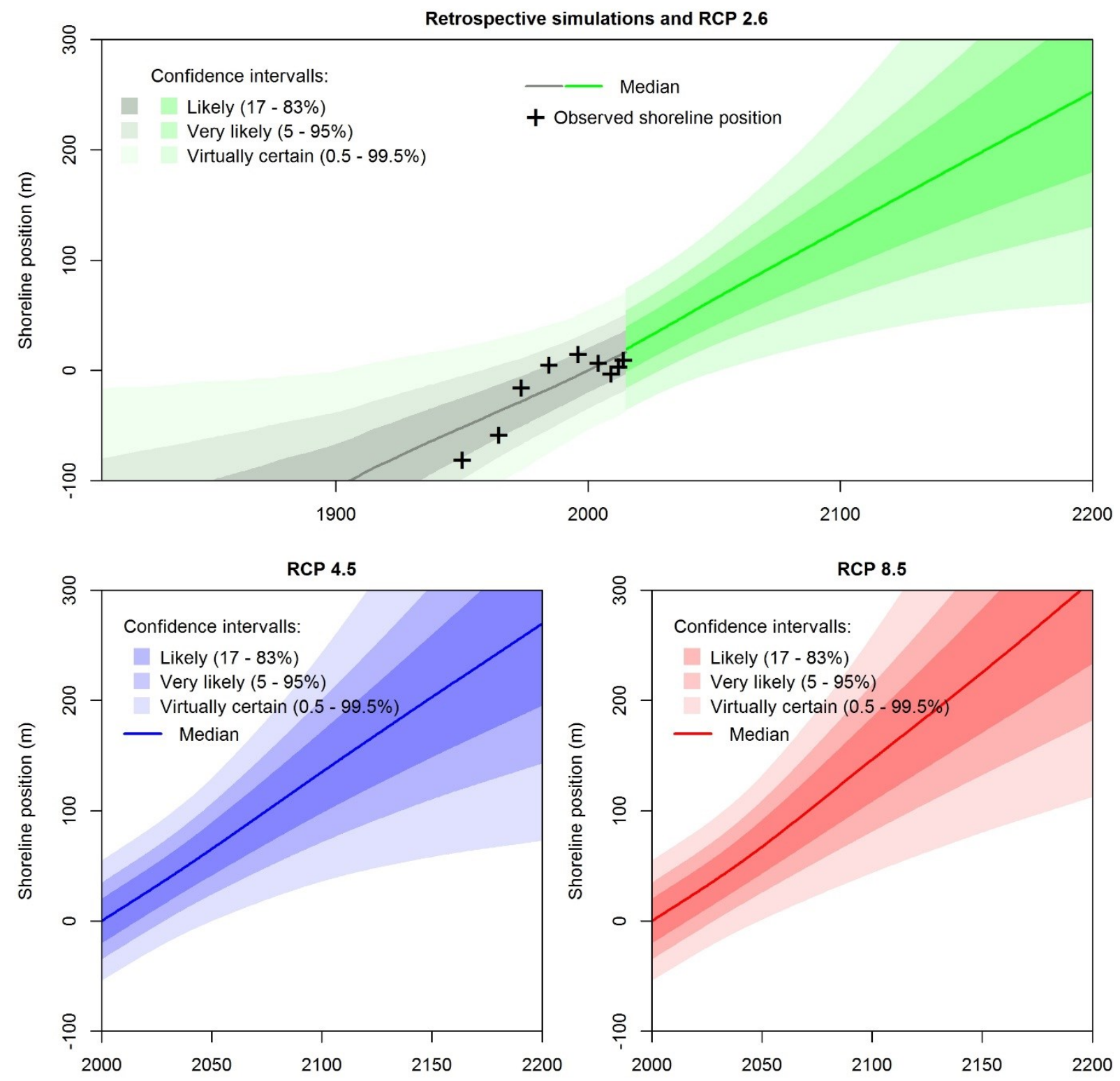

2

3 Same as Figure 2, for the site \#3.

4 

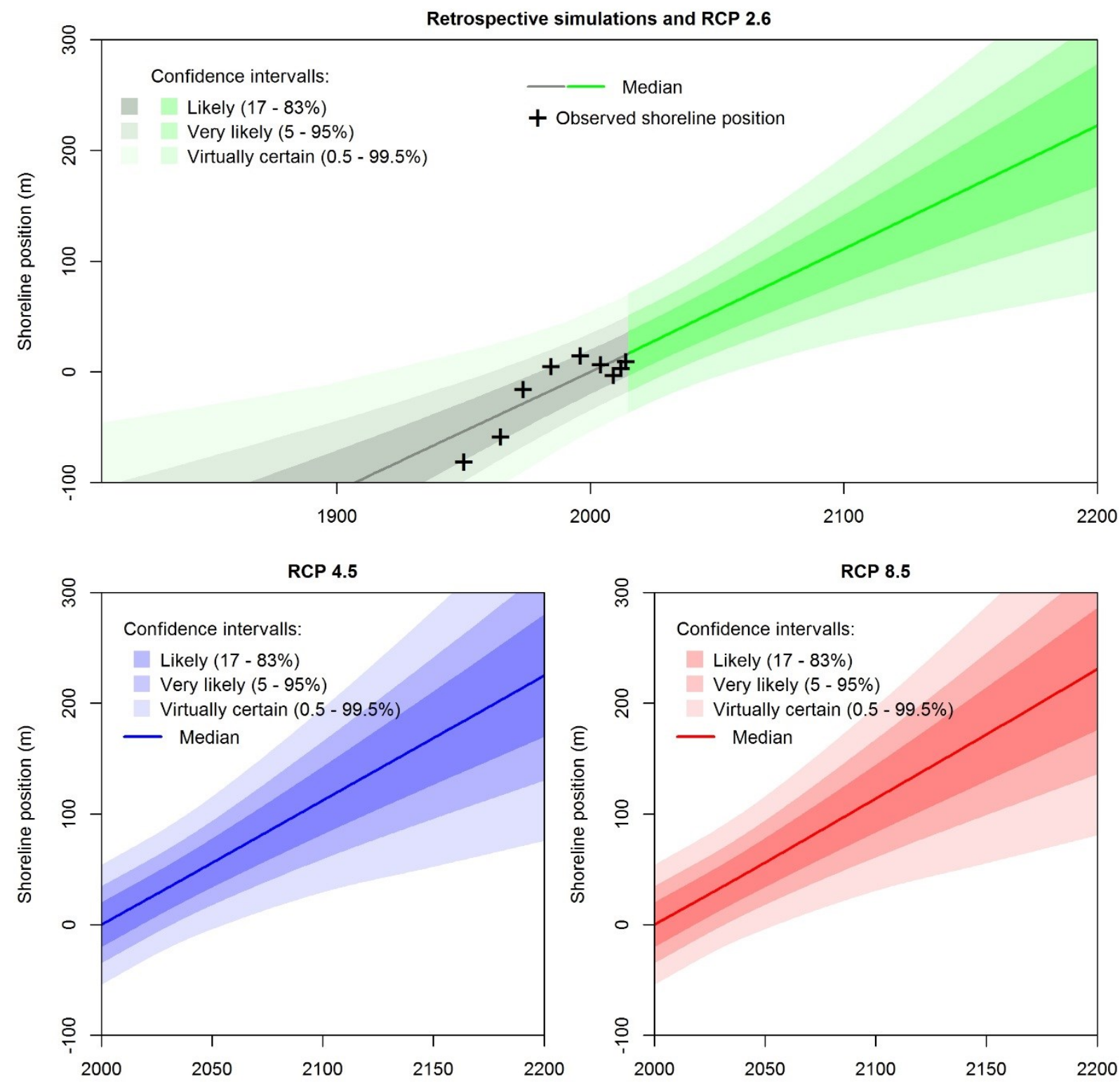

3

$4 \quad$ Same as Figure 3, for the site \#3.

5

6

7 

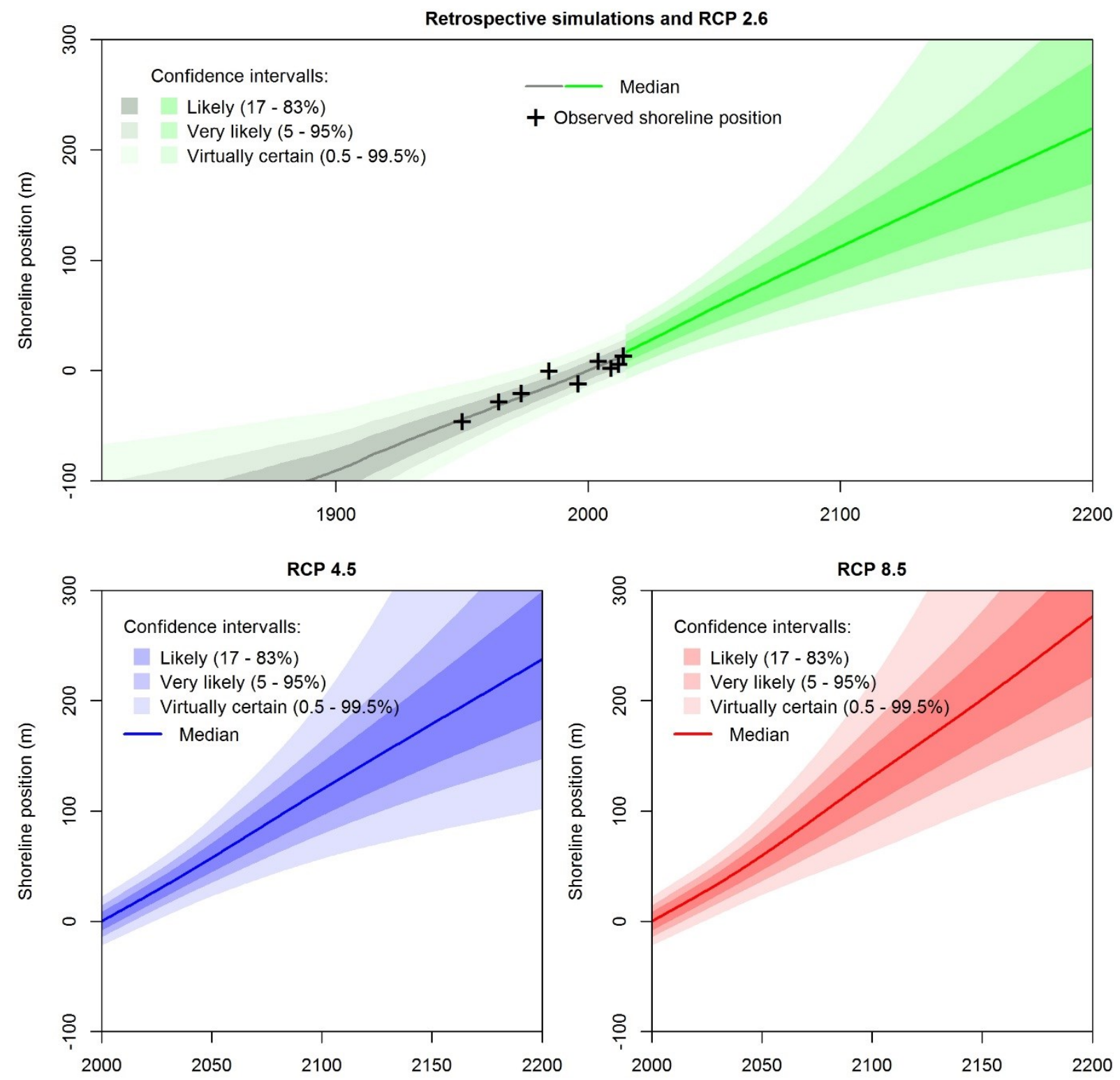

2

3 Same as Figure 2, for the site \#4.

4 

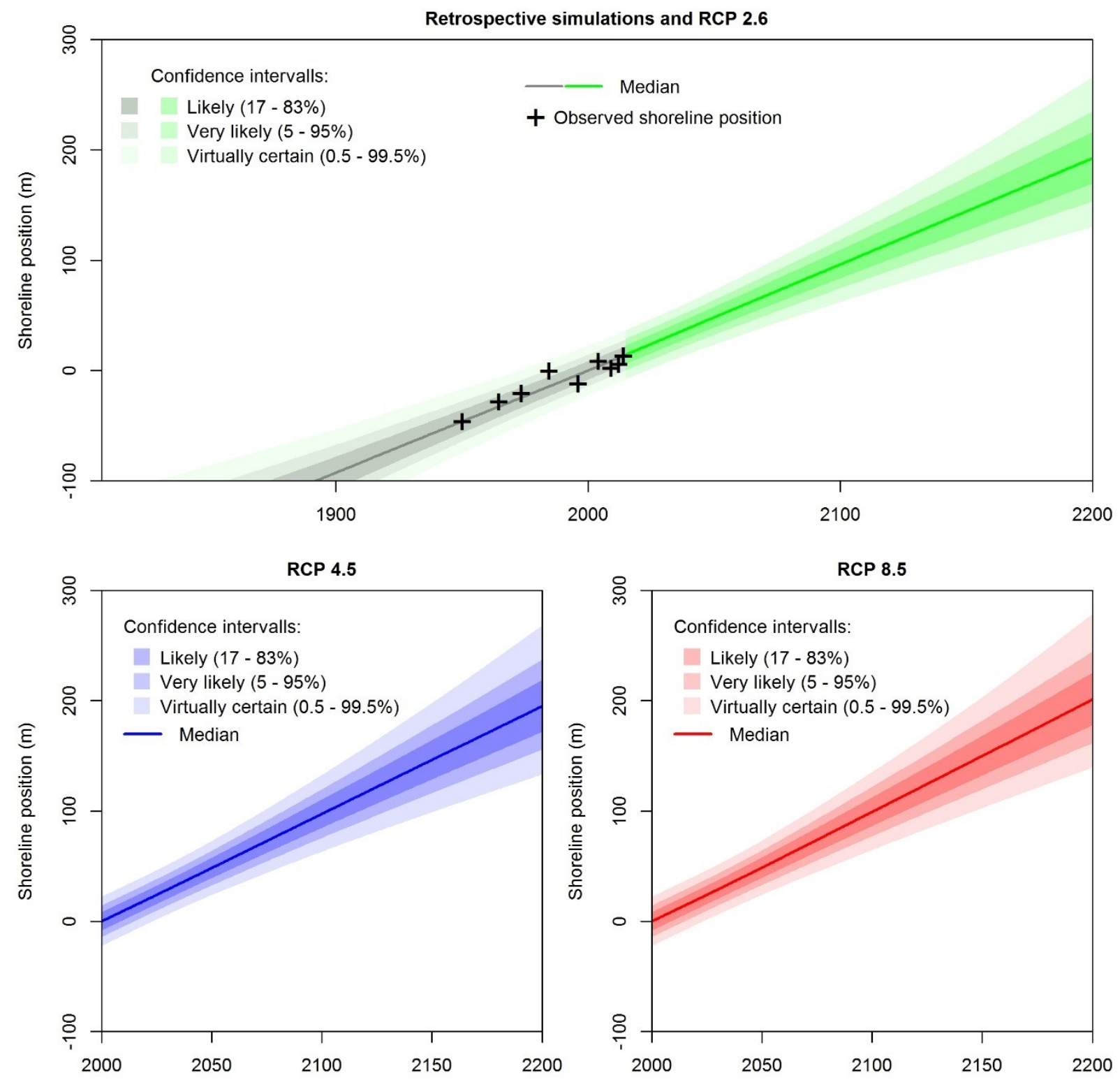

2

3 Same as Figure 3, for the site \#4.

4

5

79. 